\title{
ONLY GREEKS AT THE OLYMPICS? RECONSIDERING THE RULE AGAINST NON-GREEKS AT 'PANHELLENIC' GAMES
}

\author{
By Sofie Remijsen
}

Summary: This paper argues that the so-called "Panhellenic" games never knew a rule excluding non-Greeks from participation. The idea that such a rule existed has been accepted since the nineteenth century, when the idea of nationality played a much stronger role in the understanding of Greekness. Recent scholarship on Greek identity and ethnicity has shown that these were flexible and constantly renegotiated concepts and that the shared culture performed and the networks formed at sanctuaries and games played an important role in this negotiation process. Not only can the role of Olympia and other sanctuaries in the formation of Greek identity now be understood without having recourse to a rule of exclusion, the flexible nature of identity also would have made it virtually impossible to the implement such a rule.

The paper starts by reconsidering the well-known episode about Alexander I at Olympia - the central source text for the supposed rule - and addresses some common assumptions about the role of the hellanodikai. It is argued that this source, while offering insights into the ethnic discourse of the fifth century $\mathrm{BC}$, does not actually prove the existence of a general rule against the participation of non-Greeks. Section two surveys the evidence for admission procedures at major agones, including the admission of boys and the exclusion of slaves. The registration of polis citizenship, often assumed to be connected to the requirement of being Greek, will be addressed in more detail in section three, which will argue that such a registration was an innovation of the Roman period, and did not aim at the limitation of admission for ideological reasons. Section four illustrates, by means of a passage from Polybius, how tensions about ethnicity could still be projected on the Olympics despite their inclusive nature.

Sofie Remijsen 'Only Greeks at the Olympics? Reconsidering the Rule against Non-Greeks at 'Panhellenic' Games' C\&M 67 (2019) 1-61. 


\section{INTRODUCTION: THE PROBLEM OF IDENTIFYING 'GREEKS'}

In 1838, in what can be regarded as the first monograph on the ancient Olympics following modern academic standards, Krause described the Olympic games as "the most splendid Hellenic Nationalfest." $1 \mathrm{He}$ chose this particular term because he regarded being Greek as a basic requirement for participation:

Das Grundgesetz, welches überhaupt bei den hellenischen Festspielen obwaltete, galt auch für die Olympien hinsichtlich der Berechtigung zur Theilnahme. Nur freien Hellenen war das Auftreten in den Kampfspielen verstattet; Zuschauer konnten auch Barbaren seyn. Sklaven waren durchaus wie von den gymnastischen Übungen, so auch von den öffentlichen Spielen ausgeschlossen. So wie sich aber die hellenische Nationalität durch Colonieen, Niederlassungen und Gründungen verschiedener Städte überall hin ausbreitete, so erhielt auch das Recht der Theilnahme eine grössere Ausdehnung. ${ }^{2}$

In his view, there was a fundamental principle (Grundgesetz) that limited the right to participate in the Panhellenic games to free men with Hellenic nationality (die hellenische Nationalität). Krause had of course observed the gradual expansion of the catchment area of the Olympics, which could indicate that such a principle was not upheld, but he instead linked the growing field of participants to the extension of Greek nationality to more cities. Later in the same work, he also explained how this rule was upheld at the Olympics: a would-be competitor had to present

* Translations of sources are my own, unless stated otherwise. Editions are only specified when relevant to the argument; the numbering of source passages, including fragments, follows the system of the editions incorporated in the TLG. I would like to thank all colleagues who kindly offered critical as well as supportive comments on various drafts of this article.

1 Krause 1838: 15: "Das glänzendste hellenische Nationalfest waren die grossen olympischen Spiele zu Olympia."

2 Krause 1838: 51-52. 
himself to the hellanodikai (the Olympic judges) and had to prove that he fulfilled the requirements before being admitted. ${ }^{3}$

Krause's work, which takes an impressive range of ancient sources into account, had a profound influence on the study of Greek athletics. His criteria for admission and the idea of a formal identity check upon registration have been repeated in numerous later discussions of the ancient Olympics, often in combination with another criterion, which in the early nineteenth century was still too self-evident to point out: participants had to be male. This picture of the ancient Olympics as an exclusive event to which only (1) Greek (2) free (3) males were admitted is still widespread in current scholarship. ${ }^{4}$ Over the last twenty years, Crowther's article "Athlete and State: Qualifying for the Olympic Games in Ancient Greece" has become the authoritative treatment of the admission at Olympia. ${ }^{5} \mathrm{He}$ argues that no specific athletic qualifications were required for admission, but concludes - similar to Krause - that "unlike the modern Olympic games these festivals were national and officially excluded all non-Greek athletes." Recently, however, Nielsen, expressed his reservations, remarking that "the Olympic authorities seem to have taken an inclusive rather than an exclusive view of who was a Greek, and there is no known instance of an athlete denied admission on account of his ethnic identity."7

Such reservations are lent weight by the recognition that Krause's picture of the Olympics as a Nationalfest with a Grundgesetz, on which this

3 Krause 1838: 131: "Diese mussten sich bei ihnen (i.e. the hellanodikai) zuvor melden und darthun, dass sie Hellenen und freie Bürger waren, ..."

4 For some recent examples of these criteria in specialized literature on sport and/or ethnicity, see Hall 2002: 154; Spivey 2004: 76; Funke 2006: 9; Nielsen 2007: 19; Weiler 2008: 183; Rutherford 2013: 265; Kyle 2014: 25.

5 Crowther 1996 (reprinted 2014). Weiler 2008 discusses the same topic and includes even more sources, but has not received such a wide reception.

6 Crowther 1996: 38 (my italics). In a later publication, Crowther pays more attention to the negotiability of Greek identity, but still discusses the topic in terms of nationalism and eligibility (2007: 69-72).

7 Nielsen 2014: 136. 
idea is ultimately based, is clearly fraught with nineteenth-century nationalist ideals. Nationality was not a category used in the ancient world. ${ }^{8}$ Greece did not have lists of citizens, as it was not politically united, nor did it levy taxes. This means that it would have been extremely difficult to control at Olympia or other sanctuaries who was 'Greek' and who was not. The term nationality is no longer used in connection to ancient Greece, but since the idea that only 'Greeks' were admitted has been maintained, this creates a problem of definition. ${ }^{9}$ Most scholars currently seem to define 'being Greek' either in terms of polis citizenship or in terms of ethnicity.

Perhaps the most common implicit assumption is that, for athletes, being Greek was a matter of polis citizenship, which, unlike nationality, was a legal category of the ancient world. ${ }^{10}$ To most ancient athletes we can attach the name of a polis. This does not actually solve the definition problem, however, but merely transfers it from the individual athlete to the city: how was it determined at the games which city was 'Greek' and which was not? The most reasonable suggestion is that this was done with reference to the theoria-network of the festival. ${ }^{11}$ Epigraphic lists of

8 See e.g. Malkin 2001: 12: "We must remember the basics: there never was a state called Hellas in antiquity, and the term 'Greek', appearing in countless titles of modern works, is really our own articulation, addressing 'from above' people whose operative identities were usually not expressed in this manner."

9 E.g. Funke 2006: 9 ("dass offenbar ein Konsens darüber bestand, wer zu den Griechen zu zählen war und damit an den Spielen teilnehmen durfte" - my italics) admits uncertainty about how Greekness was established. Weiler 2008: 181 speaks of "griechische Abstammung," which is not really more specific.

10 Crowther 1996: 39 translates $\pi \alpha \tau \rho i ́ \varsigma$ as "[Greek] city state." Cf. Crowther 2007: 70. Also Kyle 2014: 25: "members of a Greek state."

11 Rutherford 2013: 265 and 273 cautiously suggests that athletes may have been obliged to be accompanied by a theoros and that this, in combination with the control of the organizing city over who was invited, could have been a means to separate Greeks from non-Greeks. He bases this hypothesis on a lacunose sacred law from Olympia (quoted on pp. 363-65 = SEG 48.541): the incomplete lines 7-8 of this law have been interpreted as a clause about athletes lending money from theoroi to pay a fine. Other scholars implicitly assume a connection between the religious network and athletic admission, e.g. W.R. Paton in his translation of Polyb. 2.12.7-8, on the first

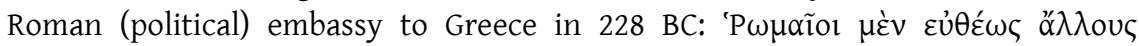

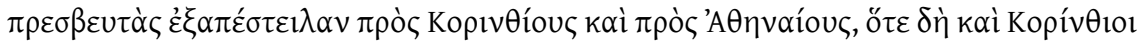


theorodokoi document which cities were invited to join in the sacrifice. For festivals with such a wide reach as Olympia, this network may have seemed to cover the entire Greek world. However, the purpose of the announcement of the festival was the declaration of inviolability (e.g. in the form of the ekecheiria or, in the Hellenistic period, of asylia) and the invitation of religious representatives; theoria decrees do not mention the invitation of athletes. ${ }^{12}$ Nor are all places on the theorodokoi lists poleis. ${ }^{13}$ It is hence no more than a hypothesis that this system played a role in the admission of athletes as Greeks. Even though it was no doubt common for athletes to be accompanied by theoroi, there is no indication in the sources that this was obligatory. The practicability of using lists of theorodokoi or the accompaniment by theoroi as criteria for admission must be questioned. The evidence does not suffice to deduce that a polis only sent out theoroi to a festival when invited to do so - they certainly sent theoroi outside the context of festivals that did not result from such invitations. Moreover, the occasional attestation of non-Greeks in theoria networks suggests that this may not have been a criterion for exclusion here either. ${ }^{14}$ It is no longer accepted in current scholarship that certain sanctuaries were open to all Greeks, but prohibited non-Greeks. There were no restrictions for the admission to widely popular healing cults

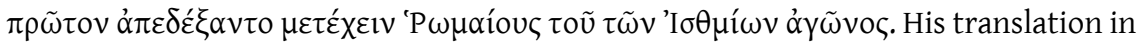
the revised version of the 2010 Loeb edition reads: “... the Romans immediately afterward sent other envoys to Athens and Corinth, on which occasion the Corinthians first admitted them to participation in the Isthmian games." $\alpha \dot{\pi} \pi \circ \delta \varepsilon \chi \chi \mu \alpha \mathrm{l}$, however, does not mean being admitted after being judged eligible. It is the verb that Polybius typically uses when describing the cordial reception of embassies (21.35.5, 21.22.1 and 3.66.8; for parallels in theoria decrees see Rigsby 1996, nrs. 8.19, 46.9, etc.). The Roman delegation, which happened to be in Corinth, was in other words "invited to join" in the festival and the Romans were henceforth included in the theoria-network of the Isthmia. It is possible that they also participated - the Byzantine epitome of Zonaras (8.19) mentions in this context that the stadion race was won by a certain Plautus but this is not what Polybius is writing about.

12 See Rigsby 1996 for examples of theoria decrees and Rutherford 2013 for a systematic discussion of the theoria.

13 Rutherford 2013: 86-88: not all places in the lists of theorodokoi were politically independent entities.

14 Rutherford 2013: 48 (Rome), 273-77 (other non-Greeks). 
and oracles. The few sanctuaries that excluded strangers did also, moreover, exclude Greek xenoi. ${ }^{15}$ In order to move forward, it does not suffice to hypothesize how an institution such as the theoria could have been used to limit athletic admission to citizens of 'Greek poleis'. Instead, we have to evaluate the premise that athletes had to be Greeks in order to be eligible for the games.

Scholars writing more explicitly about what it meant to be Greek in the ancient world now define this as an ethnic identity. ${ }^{16}$ Members of ethnic groups share a number of common traits (e.g. language, modes of self-representation, religious practices, etc.), but what defines these groups as ethnic rather than as merely cultural is that the construction of kinship ties forms an important element in the discourse about their identity. As convincingly shown by Jonathan Hall, the development of a specifically Hellenic ethnic identity can be dated to the sixth century BC, when the word 'Hellenes' (originally referring to people from a small area within Thessaly) started to be used for the entire network of Greekspeaking poleis across the Mediterranean and a genealogy around the mythical Hellen was developed. ${ }^{17}$ Such mythological kinship ties were also what athletes needed to document at Olympia in the archaic period, according to Hall. He grants, however, that this would not have worked after the 470s, when Hellenic identity began to be constructed differently. ${ }^{18}$

A central characteristic of ethnicity as it is currently understood is indeed that it is unstable and situational: the identification with ethnic

15 See Funke 2006: 4-5, 9-10. He concludes: “dass sich - wenn man es zuspitzen möchte - die Kategorie des Fremdseins nur sehr bedingt eignet, den Kreis der Teilnehmer an diesen Kulten zu differenzieren." Similarly Rutherford 2013: 2, 265-66.

16 E.g. Hall 2002: esp. 163; Spivey 2004: 76; Nielsen 2007: 20, 21.

17 Hall 2002: esp. 9-19, 125-31.

18 Hall 2002: 154-56, 159-64 proposes that the precise criterion for admission was an affiliation within one of the four Hellenic Stämme. He bases this thesis on the observation that $91.3 \%$ of the archaic victors came from cities which claimed such affiliation - note that this becomes again a definition of Greekness on the level of the polis. These statistics only prove, however, that most poleis claimed such an affiliation, not that this was a criterion at Olympia. See also p. 198 (and 227) for the suggestion that by the classical period the "Hellenic genealogy" had "outlived its functional usefulness." 
groups is (re)activated and (re)defined by specific social and political circumstances, which include tensions within the ethnic community (combatted by the reaffirmation of common traits) and external threats (addressed by underlining the differences between an 'us' and an 'other'). ${ }^{19}$ The resulting awareness that Hellenic identity too was being constantly redefined and renegotiated only exacerbates the problem of how "nonGreeks' could be identified at the games. Because of their instability, sociologists like Rogers Brubaker now even warn against the use of ethnic groups, such as 'the Greeks', as categories for research: "One is led almost automatically by the substantialist language to attribute identity, agency, interests, and will to groups." ${ }^{20}$ Instead of seemingly stable groups, one should study "how - and when - people identify themselves, perceive others, experience the world, and interpret their predicaments in racial, ethnic, or national rather than other terms" and why an awareness of an ethnic identity "can 'crystallize' in some situations while remaining latent and merely potential in others." 21

The most prestigious athletic contests of the ancient world clearly had the potential of becoming crystallization points of a shared Hellenic identity. Public athletic contests between naked citizens were typical of the lifestyle practiced in what we call the Greek world, and marked these naked men off from people who had not been socialized in this world. ${ }^{22}$ Sanctuaries such as Olympia, moreover, formed important nodes in the network of culturally Greek cities. ${ }^{23}$ Therefore, athletics and the sanctuaries where the agones took place are recurring themes in ancient discourse on Greek identity, a matter which has rightly received much attention in recent scholarship. ${ }^{24}$ The community present at the major

19 See Siapkas 2014: 5 for a good overview of the development of scholarly ideas on ethnicity. See also Luraghi 2014: esp. 221, 224 for pertinent insights on how to study ethnic identity in Antiquity, and Konstan 2001: esp. 30, 43, for a to-the-point introduction in the development of Greek identity under various political situations.

20 Brubaker 2004: 1-24, esp. 24 (quote).

21 Brubaker 2004: 18 (my italics).

22 Both Greek and Latin authors explicitly make this connection between athletic nudity and Greekness, e.g. Thuc. 1.6, Pl. Resp. 5.452c, Cic. Tusc. 4.70.

23 E.g. Morgan 1993; Hall 2002: 134-68.

24 To name just a few examples: for Herodotus, see Kyle 2010; for Pausanias' books on Olympia, see Elsner 2001; for Lucian's Anacharsis, see König 2005: 45-96. 
games was often identified as 'Hellas'. It has also been observed that activity at the Panhellenic sanctuaries spikes at the time of external crises, which again reflects the situational nature of Greek identity. This insight that the ethnic identity was in constant flux is not compatible, however, with the thesis that being Greek could, for over a millennium, have functioned as a strict criterion for the inclusion and exclusion of athletes.

It is time to reconsider whether such a rule ever existed at the games. This paper will argue that sources describing agones as games of the Greeks give us interesting evidence for the contemporary ethnic discourse, but cannot prove the existence of a rule against the participation of non-Greeks. Section one will start by reconsidering the well-known episode about Alexander I at Olympia - the central source text for the supposed rule - as well as address common assumptions about the role of the hellanodikai. Section two will then survey more broadly the evidence for admission procedures at major agones, including the admission of boys and the exclusion of slaves. The registration of polis citizenship will be addressed in more detail in section three. This section will argue that a registration procedure was only developed in the Roman period, and did not aim at the limitation of admission for ideological reasons. Section four will then illustrate, by means of a passage from Polybius, how an athlete's ethnicity could nevertheless be an aspect of the discourse on Greek identity. 


\section{HERODOTUS ON THE GREEKNESS OF ALEXANDER OF MACEDON}

The starting point for any discussion on this topic is Herodotus' anecdote on Alexander I of Macedon at Olympia (5.22), which is widely considered indisputable proof of a rule against the participation of non-Greeks. ${ }^{25}$

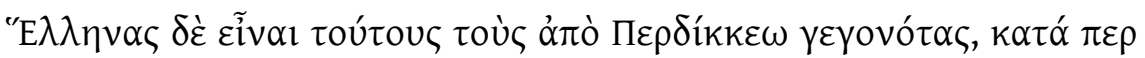

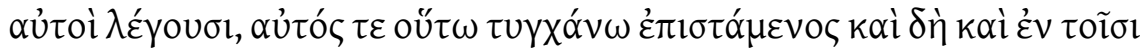

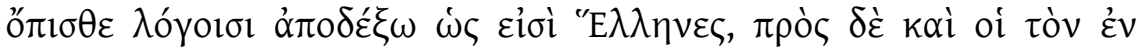

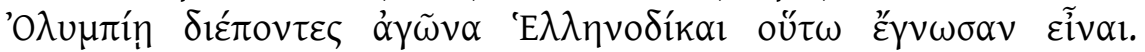

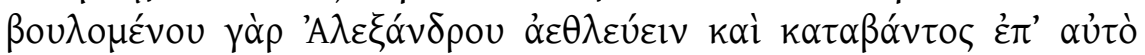

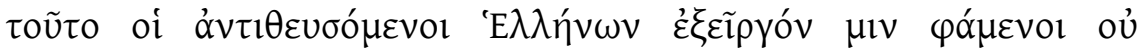

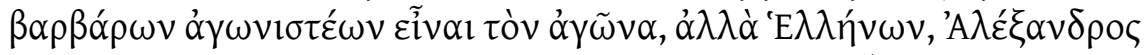

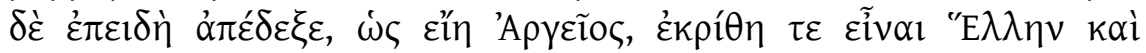

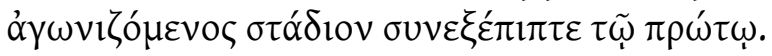

That the descendants of Perdikkas are Hellenes, as they say themselves, I happen to know myself and hence I will in the later chapters show that they are Hellenes. Besides, those who manage the contest in Olympia, the hellanodikai, have decided it is so. For when Alexander wished to compete and went down there for this very purpose, those of the Greeks who would run against him obstructed him, claiming that the contest was not for barbarian competitors but for Hellenes. Alexander then demonstrated that he was Argive, and it was decided that he was a Hellene. And when competing in the stadion race, he arrived at the finish together with the first.

Although tensions around the definition of Greekness are clearly at the center of this story, it does not actually contain straightforward evidence

25 Hdt. 2.160, in which the Eleans proudly tell Egyptian sages that the Olympics were open to both themselves and the other Hellenes, is likewise often quoted in this respect. The contrast Herodotus creates here, however, is between the Eleans and all the others who wanted to compete, not between Hellenes who could participate and 'barbarians' who could not. Cf. Nielsen 2007: 18. 
for a general rule against the participation of non-Greeks. Firstly - whatever its historical value - the anecdote presumes that the ethnicity of the participants was not checked by the judges upon the arrival of the athletes. The dispute regarding the Greekness of Alexander is indeed presented as arising in the course of the Olympics, before the stadion race was run but after the participants had become known to one another. At that point, the other sprinters objected to Alexander's participation and asked the judges to exclude him from the games. A private petition to the judges by a fellow-athlete is in line with known Olympic procedures for other issues. ${ }^{26}$ This is to be distinguished from a complaint about a previous decision by the judges, which would have been directed at the Olympic council. ${ }^{27}$ Procedures based on petitions put the initiative with the disadvantaged and hence remove the necessity for a systematic check by the authorities.

Although the details of this passage thus suggest that it was not standard to check the Greek identity of the participants, the passage as a whole does imply that it was a possible basis for exclusion from the competition. It is therefore important to note, secondly, that Herodotus does not explicitly refer to an Olympic principle. Right at the start of this passage, Herodotus discloses his agenda: this story is meant to prove that Alexander was Greek. The author tries to convince his readers of this by presenting the Olympic judges as authorities on the matter, implying along the way that barbarians would not have been admitted. He stops short, however, of presenting the exclusion of non-Greeks as an Olympic policy. On the contrary, when he chooses the participle $\varphi \alpha ́ \mu \varepsilon v o r$, he presents the idea that barbarian contenders should not be admitted not as a fact, but as a personal opinion of Alexander's fellow competitors. ${ }^{28}$ Alexander

26 Cf. Paus. 5.15.4-5, petition for a change to the program concerning the order of events. See also section 2 on the likewise reactive procedure for the exclusion of slaves.

27 Cf. Paus. 6.3.7. In this anecdote, the council fines two hellanodikai after a complaint by an athlete, but it does not revoke their decision. This suggests that there was no option for an appeal against a decision by the hellanodikai. Unfortunately, the exact role of this council is not well known, cf. Sinn 2004: 110-11.

28 Cf. LSJ s.v. $\varphi \eta \mu i ́$. 
accepts their premise when he answers the charge by playing "the genealogical game à la grecque." 29 This reaction and the settlement of the dispute in Alexander's favor remove from the narrative the need for a verdict about the more fundamental point, that is whether this was an acceptable ground for exclusion or not.

When interpreting this passage as evidence for the admission procedures at the Olympic games it is important to pay attention to such details and to read against the grain, in order to separate the author's rhetorical strategy from verifiable details about admission. But in order to be able to recognize which details in the story might be primarily strategic, we first need to establish whether or not Alexander's participation at Olympia is historical and when it took place.

It is safe to accept that Alexander indeed took part in an Olympic stadion race, since other sources confirm Alexander's interest in athletics. Justin's epitome of the histories of Pompeius Trogus states that Alexander contended in various disciplines. ${ }^{30}$ Two fragments of a poem by Pindar (frr. 120 and 121) can almost certainly be connected to a victory by Alexander I, as the first fragment names the victor the "son of Amyntas" and the second is explicitly connected to Alexander by Dionysius of Halicarnassus (Dem. 26). A much later text by Solinus also connects Alexander to Pindar and claims that the Macedonian king sent golden statues to Apollo in Delphi and to Zeus in Elis, suggesting an interest in multiple Panhellenic sanctuaries. ${ }^{31}$ Where and in which discipline Alexander obtained the victory praised by Pindar cannot be identified, but it cannot have been in the Olympic stadion race, as Alexander's name does not appear in the list of stadion victors. ${ }^{32}$ Whether "arriving at the finish together with the first" refers to a real dead heat or just elegantly avoids saying that Alexander came second, the phrase certainly makes clear

29 Quote from Hall 2002: 156.

30 Just. Epit. 7.2.14: cui Alexandro tanta omnium virtutum naturae ornamenta extitere ut etiam Olympio certamine vario ludicrorum genere contenderet.

31 Solinus Collectanea rerum mirabilium 9.13-14.

32 Bernardini \& di Marzio 2012: 33 interpret this an ex aequo solved (to the disadvantage of Alexander) by drawing lots and propose that Pindar was commissioned to celebrate this almost-victory. A traditional victory, however, remains the better occasion for epinician poetry. 
that he was not proclaimed as victor in this event. The evidence therefore suggests that Alexander took part in several athletic competitions and won at least once.

The identification of Alexander as a sprinter sheds light on the date of his participation. Because Herodotus' anecdote establishing Alexander's right to compete logically ought to refer to his first participation, it should probably be dated before the victory praised by Pindar. Because Pindar's earliest known ode (Pyth. 10) dates from 498 BC, Alexander's first participation in the Olympics can hardly have predated the Olympics of $508 \mathrm{BC}$. The king took over the Macedonian throne at some point in the early or mid-490s and reigned until circa 454. Most scholars suggest a date of birth between 530 and 525, which means that he ascended the throne in his early thirties and died in his seventies. ${ }^{33}$ His athletic career must be placed in his teens (in the boys' category), twenties or early thirties. The ancient Olympic stadion race required great physical talent and prime form, certainly in the late sixth and early fifth century $\mathrm{BC}$, when the sprinting scene was dominated by star athletes from Croton. ${ }^{34} \mathrm{~A}$ date between 508 and 496 is compatible with the known data on his lifespan. ${ }^{35}$ If Alexander indeed came second in a dead heat, the safest guess would be $500 \mathrm{BC}$. In this year, the stadion victory was obtained by a man from the Locrian city of Opous, which suggests that this was an Olympiad with a more level playing field than in the surrounding years when Crotonian

33 Kertész 2005: 117-19 usefully summarizes the arguments of Hammond and Dascalakis (advocating for a date of birth between 530 and 525) and Errington (suggesting a date of birth in the 510s). The main argument in this discussion is whether the marriage of Alexander's sister to the Persian Bubares (Herodotus 5.20-21) should be dated to the late sixth (as Herodotus suggests) or to the early fifth century. For a detailed argumentation in favor of an early date for the marriage and hence Alexander's lifespan, see Badian 1994: 108-12.

34 Moretti 1957: nrs. 148 and 153 (Ischomachos in 508 and 504 BC), 166 and 172 (Tisikrates in 496 and 492), 178, 186 and 196 (Astylos in 488, 484 and 480). In 484 and 480, Astylos no longer competed as Crotonian, but as Syracusan after accepting a bribe.

35 Dascalakis 1965: 159 suggests 496. Roos 1985: 167 proposes a date before 496. More recently, Engels 2010: 93 has suggested 504 or 500 (although in the same companion Sprawski 2010: 142 follows Kertész) and Bernardini \& di Marzio 2012: 34-38 have accepted 496 as the best option (for the Pindaric ode, which they do connect to the anecdote of Herodotus). 
stars dominated the scene. ${ }^{36}$ Alexander would have been in his midtwenties, like most modern victors of the Olympic $200 \mathrm{~m}$. He would still have been young enough to compete again in the 490s and this successful second participation would fall within the known limits of Pindar's career. Some scholars have suggested, however, a participation as late as $476 \mathrm{BC}$, using the king's prior support of the Persians as an argument against earlier participation. ${ }^{37}$ This argument does not stand up: we know of several early fifth-century victors from cities that sided with the Persians. ${ }^{38}$ It is unlikely that a king in his forties or fifties would have risked his tenuous reputation by wanting to compete with the cream of sprinters in $476 .^{39}$

While it is reasonable to accept the historicity of Alexander's participation at Olympia circa $500 \mathrm{BC}$, this does not make it safe to accept all details in the story as accurate. More than fifty years intervene between Alexander's participation and Herodotus' version of these events. Donald

36 Moretti 1957: nr. 159.

37 See e.g. Badian 1982: 34: "The date is not attested, but 476, the first opportunity after the war, seems a reasonable guess." For the most detailed argument for 476, see Kertész 2005. He starts from the premise (p. 117) that Alexander's international policy otherwise does not make sense (i.e. Alexander would not have supported the Persians if he was already accepted as Greek; therefore, since he supported the Persians, he cannot have been accepted as Greek, and he cannot have entered the Olympics). I do not accept the premise that a participation in the Olympics and the potentially ensuing perception of Alexander as a Hellene (which was far from general anyway) would have affected Alexander's strategic foreign policy decisions.

38 More traditionally Greek areas, such as Thessaly or Argos, medized as well in 492, and they still sent representatives to the games: 488 BC, Asopichos of Orchomenos and Hippocleas of Pelinna (Moretti 1957, nrs. 182 and 185); 480 BC, a boy wrestler from Argos, Argos as a city in the horse race and [Dae]tondas and Arsilochus of Thebes with a chariot (Moretti 1957: nrs. 204, 207, and 206; cf. P.Oxy. II 222, col. I, 11. 2, 5-6).

39 Kertész 2005 does not sufficiently address the problem of Alexander's age in 476 . He accepts a late birth in the 510s (p. 119) which puts him at almost forty instead of in his fifties and gives three examples of athletes who may still have been successful around the age of 40 (p. 126: Hipposthenes of Sparta, Milon of Croton, Theagenes of Thasos, who all had careers of more than 20 years). These are professional fighters, however, for whom a long career was more common than for sprinters. The victories that they obtained at the age of about 40 were, moreover, their last victories, not their first. 
Kyle has shown that Herodotus, who wrote between the 450 s and the 430s, consistently represents athletics as a custom that unites the Greeks in order to mask the many tensions between poleis and other political organizations in the period leading up to the Peloponnesian war. ${ }^{40}$ The telling of the Alexander episode was also prompted by such contemporary concerns. In the mid-fifth century BC, the Macedonian court was faced with the challenge of getting accepted into the Greek community that had come into focus in the aftermath of the Persian wars. Herodotus knew that the status of Macedonia as Greek was disputed and says outright that the purpose of this passage was to prove that the Macedonian royals were indeed Greeks. It is important to look closer at how he constructs his argument.

In a fictional speech of the Athenians to a Spartan delegation (8.144), Herodotus famously lists four common traits of the Greeks: blood, language, cults and customs. He ignores the aspect of language in his proMacedonian argument, but indirectly refers to the others. In 8.137-38, the later passage referred to in the Olympic anecdote, he focuses on the blood shared between the Macedonian royals and the Greeks, through their assertion of kinship ties to Argos. In 5.22, the Olympic episode, he also refers to the Argive connection, but focuses mainly on shared cults and practices: Alexander visited the Olympic sanctuary and competed there. Opponents of the Macedonian claim to Greekness could of course respond to this that Alexander's claimed genealogy and presence at Olympia showed only that he wanted to be Greek, not that he was. Herodotus, however, tries to preemptively counter this critique - put in the mouth of Alexander's opponents - by referring to the authority of the Elean judges. The historian frames Alexander's willingness to engage in a Hellenic practice between two explicit references to the decision of the

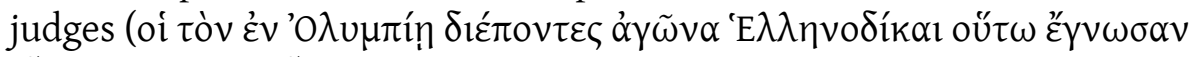

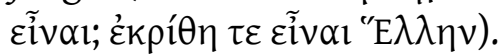

Because he presents it as an answer to a petition, the historian does not actually say that checking the Greek credentials of Olympic participants was a standard task of the judges, but their title, hellanodikai, invites the readers to interpret it as such. ${ }^{41}$ Modern scholars often accept

40 Kyle 2010.

41 See Sinn 2004: 108-10 for a short survey of their tasks. 
this suggestion and interpret this title in the context of this passage as 'judges of Greekness'. ${ }^{42}$ A more neutral reading of the title, however, is 'judges of the Greeks (competing there)'. A scholion on Pindar confirms the latter interpretation: "Those who regulate the contest are called hellanodikai, because only Greeks compete." ${ }^{43}$ This scholion, as well as the title it discusses, unambiguously illustrates that athletics was seen as a Greek habit, but they do not say that this had to be checked.

There are, moreover, several problems with the hellanodikai in this passage. Firstly, this word does not appear in all manuscripts, so we cannot be sure whether Herodotus actually used it. The edition quoted above is the 1997 Teubner edition by Rosén, which follows the manuscripts of

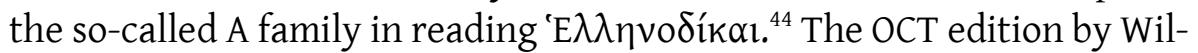
son, on the other hand, favors the manuscripts of the so-called Roman

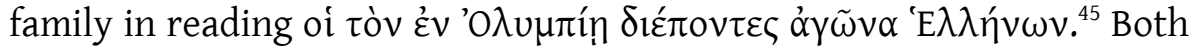
readings fit Herodotus' aim to present the Olympics as something typically Greek, but the word hellanodikai is far more suggestive about the judge's authority to assess ethnic claims than 'those who manage the contest of the Greeks at Olympia'.

Secondly, the hellanodikai represent an anachronism. Although the title hellanodikes was well-established by the time Herodotus was writing, this was not the case around $500 \mathrm{BC}$ when Alexander participated. Bronze tablets from the later sixth century call the judge of the Olympic wrestling a diaitater. ${ }^{46}$ The first attestations of the word hellanodikes are the third Olympic ode of Pindar (from 476) and IvO 2 (circa 475-450). ${ }^{47}$ Although the date of the Pindaric ode technically offers only a terminus ante quem, it is by now generally accepted that the Olympics of 476 were the

42 E.g. Hornblower 2013: 117: "The very name ... perhaps also implies that one of their functions was to adjudicate about Greekness."

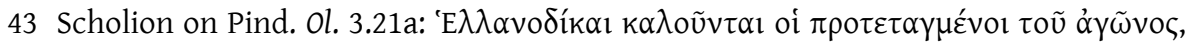

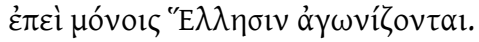

44 Similarly the Budé edition by Legrand.

45 See Wilson 2015: xiii-xviii for a survey of the manuscripts and their relation to one another.

46 SEG $48.541=$ Neue Inschriften von Olympia $2(525-500$ BC) and the new tablet published in Siewert \& Taita 2014.

47 The inscription is dated paleographically. The older dating around 580 BC is no longer accepted, see Nielsen 2007: 19-20 and Zoumbaki 2011: 8. 
first edition in which this title was used. ${ }^{48}$ This is linked to a broader debate about ethnic sensitivities at the 'Panhellenic' sanctuaries. Nielsen has shown that the Greek identity of competitors was not on the Olympic agenda before the early fifth century ${ }^{49}$ Inscriptions confirm his view: in the second quarter of the fifth century the word "E $\lambda \lambda \eta v \varepsilon \varsigma$ starts to appear frequently in victory epigrams. It denotes the community witnessing the victory, but interestingly never the victor himself. ${ }^{50}$ Morgan's recent study of the political communication of the Sicilian tyrants confirms that, although participation by these rulers in 'Panhellenic' contests had a long tradition, it was only in the 470s that it became important to underline in this context how they represented the Greek community. ${ }^{51}$ Both scholars connect the emerging awareness that athletic contests were typically Greek to the political context of the Persian wars. It was in particular the collaborative effort in the battles of Salamis and Plataea that functioned as a crystallization point for a shared Greek identity circa 480-479. ${ }^{52}$ The great Panhellenic enthusiasm around 479 is, for example, visible in the erection of a common victory monument at Delphi. ${ }^{53}$ The restyling of the diaitateres as hellanodikai was likewise a programmatic articulation of the Panhellenic character of the Olympic contest. A contemporary parallel can be found in the context of the Delian league, which upon its formation in $477 \mathrm{BC}$ gave its treasurers the equally programmatic name hellenotamiai. ${ }^{54}$

The lack of evidence for ethnic sensitivities or hellanodikai at the Olympics before 479 makes it dangerous to accept at face value that circa

48 Zoumbaki 2011: 7-9, with references to older literature.

49 Nielsen 2007: 19-20.

50 See e.g. Ebert 1972: nrs. 20, 37, 38, 56, 59, 65, 67, 69, 73, and 81.

51 Morgan 2015: 134-35.

52 Cf. Hall 2002: 172-89. The earlier battle of Marathon was an Athenian, not a Panhellenic success. See Zahrnt 2010: 114-27.

53 Herodotus 9.81. For further sources and the inscription see West 1966: nr. 25. Other bodies also set up victory commemorations at Delphi in the 470s, representing competing statements of Greekness in the same space: cf. Scott 2010: 81-91. In the same period, for example, the Deinomids too presented their victories as obtained against the 'barbarians' for the freedom of the Greeks. See Morgan 2015: 31-45 for the different building phases of this monument and its inscriptions.

54 Baron 2013. 
500 BC Alexander's opponents complained about the Macedonian's ethnicity. It is more likely that Alexander's performance at Olympia was at the time a rather colorless event, but that it could be reinterpreted in ethnic terms from 479 onwards, when it had become important for Alexander to present himself as Greek. By now middle-aged, he could no longer make a statement by taking part in the race, but the emerging panhellenism had created an opportunity for pro-Macedonian thinkers to re-narrate his defeat at Olympia as a personal victory. ${ }^{55}$ The addition of a story about an ethnic dispute between him and his opponents would have been difficult to disprove decennia afterwards. The problem with petitions is that only the effect of a decision would be noticeable to the public; the decision-making process would have been followed by few more than the parties involved. By the time the Histories were read, these few witnesses were dead. The combination, on the other hand, of an oral tradition about Alexander's participation and a political climate in which ethnic claims of the Macedonian royals were disputed granted the story some plausibility.

This does not mean, however, that Herodotus' readers would have been as ready as their modern counterparts to accept the authority of the Olympic judges on matters of ethnicity suggested by this anecdote. The ethnic identity of the Macedonian kings remained a matter of dispute. No other authors follow Herodotus' example of referring to the hellanodikai as part of an argument on ethnicity. One can even wonder whether Herodotus himself was as convinced of the argument as he claimed to be. Badian has pointed out that he seems to steer his readers towards the opposite conclusion when he divides the arguments in favor of Alexander's Hellenic identity over two anecdotes and inserts the first one (the Olympic episode) immediately after the description of how Alexander gave a high-ranking Persian a large sum of money, as well as his sister in marriage, and the second one (the genealogy) in the story about

55 The suggestion that the story was a form of Macedonian propaganda is also found in Borza 1982: 11 and Asirvatham 2010:101. The former rightly underlines the reliance of Herodotus on his Macedonian sources, and the lack of independent confirmation of the story. The latter even doubts the participation of Alexander at Olympia because he is not listed in the list of stadion victors, but it has already been noted that Herodotus does not actually claim that he was proclaimed as victor. 
Alexander's visit to Athens in the service of the Persian king, when he was thrown out of the city after "his most conspicuous act of medism." 56

All the same, and irrespective of its historicity or persuasiveness, the story documents that when it was written in the mid-fifth century, it was possible to think of the Olympics as an exclusively Greek event. Whereas Nielsen suggested that at the time of the encounter with the Persians the exclusion of non-Greeks became fixed as an Olympic rule, I would go one step further and argue that the idea that the Olympics were something Greek was indeed strongly felt circa 479 and even became petrified in the new title of the Olympic judges, but never took the shape of a formal rule of exclusion. Herodotus mentions neither an admission procedure nor an ideological principle, and it has already been noted that in the whole history of the games there is not a single known case of exclusion on ethnic grounds. ${ }^{57}$ In order to develop further this thesis that Greek identity never became an official criterion for exclusion from the Olympics or from any of the other major games, a more thorough survey of the available evidence for registration and admission procedures at these games is necessary.

56 Badian 1994: 119-20. Borza 1982: 8-11, on the other hand, describes Herodotus as proMacedonian.

57 Cf. Nielsen 2014: 136. 


\section{WELL-ATTESTED PROCEDURES AND RULES FOR ADMISSION}

\section{The enkrisis procedure}

The only known technical term for a selection procedure before an agon is enkrisis, a word derived from Éүкpíveıv, 'to examine and include in the

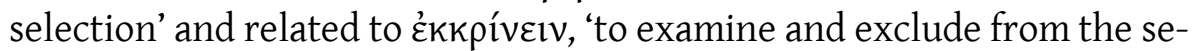
lection'. This particular examination did not, however, admit athletes to the contest in general, but specifically admitted young athletes to the youth competitions. ${ }^{58}$ All agones had at least two age categories ( $\dot{\eta} \lambda ı k i ́ \alpha$

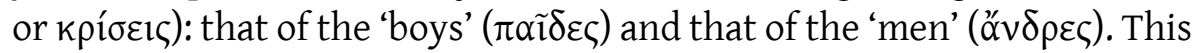
simple distinction between adults and under-age athletes goes back to the archaic period. In Olympia, no additional age categories were ever added, but in many other contests, an intermediate category for the older boys ('̊y $\varepsilon^{\prime} v \varepsilon 101$, litt. 'beardless') was introduced in the classical period. This category is well attested in classical Athens and was also used at the Isthmian games in the early fourth century. From the third century BC on, when the category of the ageneioi had become widespread, some contests introduced other subdivisions of the youngest participants. Best attested is the combination of 'Pythian boys' and 'Isthmian boys' (terms used at games that were neither Pythian or Isthmian). Because these groups are typically mentioned in this order, and are then followed by the ageneioi and the men, it is clear that the Pythian boys were younger than the Isthmian boys, but we can only speculate about the approximate age limits. ${ }^{59}$

58 Most references to the enkrisis deal explicitly with age categories. Lucian (Pro imaginibus 11) and Aelius Aristides (Or. 29.18), however, use the general description $\dot{\eta} \tau \tilde{\omega} v$ $\dot{\alpha} \theta \lambda \eta \tau \tilde{\omega} \nu$ है $\gamma \kappa \rho ı \jmath \iota$ (the enkrisis of the athletes), without specifying that these athletes were boys. In both texts the enkrisis serves as a parallel for other types of examinations (of the size of statues and of would-be teachers respectively), the latter representing the actual topic of the passage. The enkrisis is hence called 'of the athletes' to place the procedure within the athletic sphere, so that the comparison is intelligible, and need not imply that all athletes underwent the procedure.

59 Klee 1918: 46 proposes for the Pythian boys 12 to 14 years, for the Isthmian boys 14 to 17 and for the ageneioi 17 to 20 . Most evidence regarding the age categories is collected in Frisch 1988. For further discussion see Golden 1998: 104-16. I do not accept 
Although at least some games specified age limits for these categories $^{60}$, the focus on the size of boys in the sources on the enkrisis suggests that the main criterion for admission to a category was physical development rather than age. The earliest literary reference to the enkrisis of young athletes is Xenophon, who describes how Agesilaos II used his personal influence in Olympia to get a young man admitted in the category of the boys, although he was taller than any of the other boys. ${ }^{61}$ Eratosthenes - preserved through Favorinus, who is in turn quoted by Diogenes

Golden's suggestion that the Isthmian and Nemean games may have had the category of ageneioi from their start in the sixth century, as the evidence is tenuous until IAG 22 (ca. 400-350 BC, Isthmian victor in the pankration for ageneioi). For all evidence of Isthmian victors see Farrington 2012. Since the category of the ageneioi is particularly well-attested in classical Athens (e.g. IG II ${ }^{2} 2311$, Pl. Leg. 833c, Lys. 21.4), and since Pindar uses the word only twice, once in connection to the Athenian trainer Melesias (Ol. 8.54) and once for a contest at Marathon (Ol.9.89), it is more likely that this category spread from Athens, perhaps due to this city's cultural influence in the fifth century.

60 This is suggested by IVO 56 (on the rules of the Sebasta in Naples), 11. 10-12: [- - -

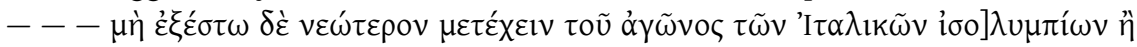

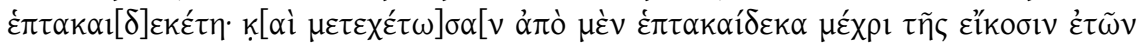

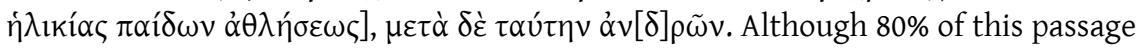
is added by the editor and hence purely hypothetical, the few legible passages do make clear that these lines dealt with age limitations and that 17 was a cut-off point.

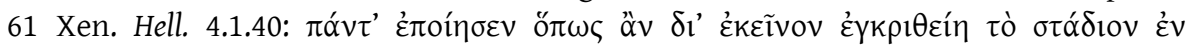

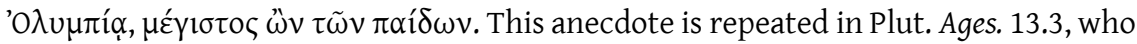
likewise explains that the boy was in danger of being excluded from the boys' race

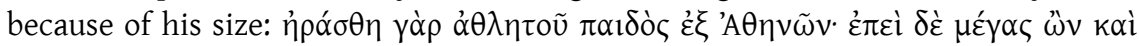

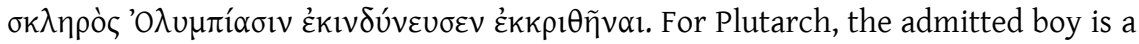
young Athenian athlete, fancied by a young and noble Persian refugee in Sparta, who was in turn fancied by Agesilaos. The original passage in Xenophon, however, is ambiguous. Whereas most translations reflect Plutarch's reading, Bresson suggests that Agesilaos had his beloved young Persian refugee admitted, because this young man wanted to be together with the (younger) object of his own desire, a Spartan boy called Athenaios. See Bresson 2002: 28-41. If Bresson is right that a young (though clearly fully acculturated) Persian participated in the Olympics, it is even more telling that Xenophon focuses on his size as the reason why he could not get through the enkrisis without royal pressure on the hellanodikai and does not raise the young man's ethnicity as an issue. It is also telling - and consistent with my argument in 
Laertius - mentions an earlier case: Pythagoras of Samos was excluded from the competition for boys in $588 \mathrm{BC}$ - as well as mocked for his effeminate long hair and colorful robe - but then won the men's boxing. ${ }^{62}$ Whether or not this anecdote is true, it is likely that the enkrisis indeed goes back to the archaic period, as conflicts about the placement of athletes on the verge of becoming men would have arisen as soon as contests for boys were held.

Because the enkrisis was not an examination for all athletes, it did not determine whether one belonged in the category of the boys or that of the men. It was only in place for competitors who wanted to compete in a youth category, and who could either be included or excluded. Explicit statements that adult athletes did not undergo this formal examination can be found in works from the second and third centuries AD. Artemidorus explains in his book on The Interpretation of Dreams that for most people it was auspicious to dream of passing the enkrisis, but not for athletes: "For boy athletes it is not significant, because they fall within the age limit of the enkrisis; for adult athletes, on the other hand, it is a bad sign, since the enkrisis is something for boys." ${ }^{63}$ This distinction between underage and adult athletes is also made for dreaming that one is a boy conquering a man in a wrestling match. This was generally a positive sign, except for boy athletes, because this predicted exclusion from the category of the boys (1.60). Similarly, it was inauspicious to dream about being an ephebe, "as this predicts that he will be excluded for being over the age limit" (1.54). A dream about not passing the enkrisis was of course inauspicious for all; it could even predict death (1.59). In Artemidorus' fifth book, this is illustrated with an example in which the god Asklepios acts as examiner. According to the description, the examination of a boy consisted of being scrutinized while walking past the divine examiner (кpıтńs) together with the other boys (5.13). The relative frequency of

the later section on citizenship - that more than four centuries later Plutarch assumes that citizenship was an issue at Olympia and therefore that the boy who benefitted from Agesilaos' help must have been the younger boy.

62 Diog. Laert. 8.47-48. The anecdote is repeated - in very similar words - in the Olympic victor list of Euseb. Chron. Ol. 48. (ed. Christesen \& Martirosova-Torlone 2006)

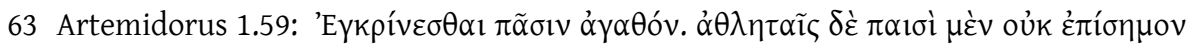

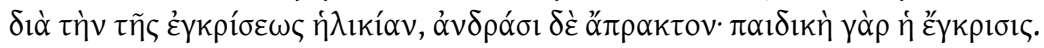


the enkrisis in The Interpretation of Dreams illustrates well that growing bigger and stronger was not only a gift but also a worry for talented boys: it increased both their odds of winning the boys' competition and those of being excluded from it.

Pausanias too refers to the examiners: in a passage on the oath sworn by the athletes at the statue of Zeus Horkios in Olympia, he writes that

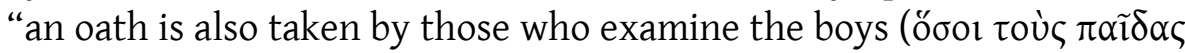
... kpívouolv), or the foals entering for races, that they will decide fairly and without taking bribes, and that they will keep secret what they learn about a candidate, whether accepted or not." ${ }^{64}$ Examiners of the adult athletes are again not mentioned, nor are criteria, but the feature connecting boys with foals is obviously their non-adult status.

More details about the practical organization of the enkrisis are known from Isthmia, where young competitors of the Isthmian games wanted to qualify either for the category of the boys or for that of the ageneioi. In the second century, a benefactor paid for several buildings, including ex-

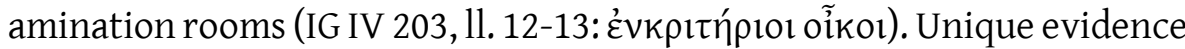
about how the local team of examiners reached their decisions is offered by four lead ballots, all from the imperial era. ${ }^{65}$ SEG 32.364, the only complete one, shows the basic formula: I, Marius Tyrannus, exclude Simakos

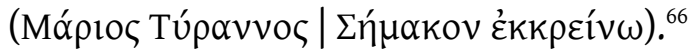

It is unlikely that the exact procedure of which we find traces in the works of Artemidorus and Pausanias or in the Isthmian ballots had been in place since the archaic period. With the duplication of the age categories of most agones from the fourth century BC onward, the number of decisions to be taken increased proportionally. Around the same time, in

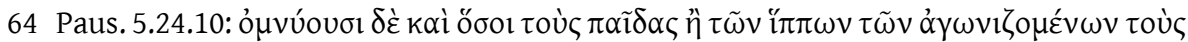

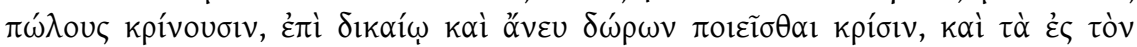

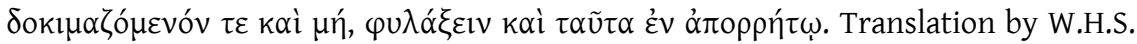
Jones \& H.A. Ormerod (LCL 188).

65 SEG 32.364, 44.305-307. Cf. Jordan \& Spawforth 1982: 65-68; Jordan 1994: 111-26.

$66 \Sigma$ ń $\mu \alpha \kappa o \varsigma$, the name as written on the ballot, is unique and therefore most likely a misspelling - with $\mathrm{l}, \eta, \varepsilon l, o l, v$ and $\gamma$ all pronounced as $i$ in the Roman period, such mistakes are common. Jordan identifies the name as Lí $\mu \alpha$ kos, which is common in inscriptions from the later Hellenistic period from Butrint (Epirus), but rare elsewhere (only nine attestations outside Epirus in the PHI database). Symmachos, which phonetically sounded similar, was far more common. 
the late classical and Hellenistic period, one can see an increasing separation of work between contest presidents and contest judges: the organization and financial administration came into the hands of agonothetai, who enjoyed more prestige than judges such as the hellanodikai, who supervised the actual contests. ${ }^{67}$ Some of these judges retained the traditional names, for example the hellanodikai, but at some games there were specific judges named enkritai after their role in the examination. ${ }^{68}$

\section{The exclusion of slaves}

Although the sources clearly show that the enkrisis was for underage athletes only, it is still widely assumed that adult athletes also underwent some kind of admission procedure. The central source text in this discussion is a passage in Philostratus' Gymnasticus: "a hellanodikes or amphiktyon decides about a boy athlete according to the following: whether he has a phyle and patris, whether he has a father and family, whether he belongs to the free men and is not illegitimate, and above all, whether he

67 On the development of the agonothesia, see Papakonstantinou 2016. Epigraphically, the agonothetai overshadow the judges because their office required capital, which made it more interesting for purposes of self-promotion. The title hellanodikai was taken over by various other contests in the third century, cf. Zoumbaki 2011: 12-21. By the imperial period, the hellanodikai were clearly low in the hierarchy. Pausanias mentions them often, but always in connection with the practical organization of the contest: purification before rituals (5.16.8); specialization in a specific discipline from $400 \mathrm{BC}$ on (5.9.5); supervision of the obligatory training in the gymnasium of Elis in the month before the Olympics (6.23.2); dealing with petitions by athletes (6.15.5); deciding which competitor had won (6.3.7; 6.13.9; 8.40.1-2); imposing fines $(5.21 ; 6.6 .6 ; 6.9 .6)$; keeping records $(6.2 .3 ; 6.7 .1)$. Since Pausanias is the main source on the activities of hellanodikai it is significant that he says nothing about them checking ethnic credentials.

68 See SEG 3.369, a fragmentary inscription from Lebadeia, perhaps from the first century BC and probably connected to the Basileia. Heberdey \& Wilhelm 1896: 30 nr. 68 is an imperial-age inscription from Cilicia for a wrestler who had, under the Ėvkpı $\alpha$ í headed by Zenon, won a local agon instituted by a Herakleides alias Herodoros. The fact that the athlete obtained his wrestling victory in the category of the boys can help to explain this unique occurrence of the examiners as eponymous officials. 
is young and not over the age limit of the boys." ${ }^{69}$ Immediately after this, Philostratus lists a series of other psychological and physical traits, all likewise duplicated into pairs of connected traits, which were examined by a gymnastes but not by the judges at contests ${ }^{70}$. Philostratus' explanation of the enkrisis therefore serves as contrast with the gymnastes' knowledge of physiognomy (that is, the complete analysis of body and temperament), which is not limited to a certain age and which is a central theme in this treatise.

Like the previously discussed authors, Philostratus points out that the main ( $\dot{\varepsilon} i \dot{i} \pi \tilde{\alpha} \sigma \mathrm{lv})$ criterion for the admission of boys was their age. The other questions, however, about his phyle and patris, about his father and family, and about his legitimate birth and status as a free man, were strictly not part of the enkrisis and could equally be asked of adult athletes. They require particular attention, moreover, as they could potentially reflect two of the three requirements for participation that are postulated in modern scholarship, Greek identity and free status - the third, masculinity, would obviously not require an formal check as the athletes competed naked.

There is no reason to doubt the communis opinio that freedom from slavery was an essential qualification for all athletes. This is literally spelled out to us by various authors. Moreover, because being a slave represented a legal status, this criterion did not pose any definition problems, as an ethnic criterion would. Although we have little explicit evidence for this rule before the imperial age, the aristocratic origin and ideology of athletics suggest that the exclusion of slaves characterized

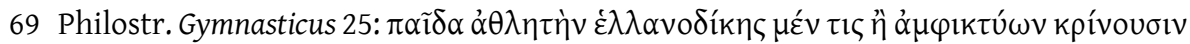

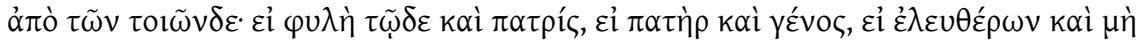

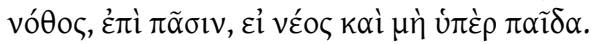

70 Weiler 2008: 190 also counts the following three pairs of qualities ( $\varepsilon \dot{i} \delta$ ' $\dot{\varepsilon} \gamma \kappa \rho \alpha \tau \dot{\eta} \varsigma \hat{\eta}$

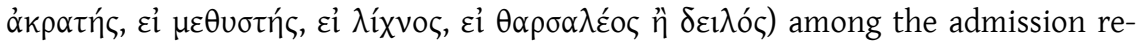
quirements checked by the judges, but the various editions of this text (the 1871 Teubner edition by Kayser, the Jüthner edition with German translation and commentary from 1909 and the 2014 Loeb edition by König) all logically place a full stop before this word group, as the end of the sentence is announced by $\dot{\varepsilon} \pi \dot{\imath} \pi \tilde{\alpha} \sigma \mathrm{lv}$. The new qualities and vices (self-control or the lack thereof, being a drunkard of a glutton, and courage and cowardice) belong to the next sentence, about what the judges are not allowed to take into account, but the trainer should. 
athletics from early on.$^{71}$ For the imperial period, Artemidorus' work On the Interpretation of Dreams confirms the evidence of Philostratus: for a slave, he writes, it was auspicious to dream of winning a sacred agon, as this predicted that he would be proclaimed a free man, "because these things are typical of free men." 72 The dream interpreter added a cautionary note that this only worked for contests that had the status of being 'sacred'. Slaves were indeed allowed to compete in some local festivals. ${ }^{73}$

Explicit information on how slaves were excluded in practice can be found in a late-antique athletic metaphor appearing in two sermons by John Chrysostom. Preaching in the late fourth and early fifth centuries, John Chrysostom used a large number of athletic metaphors that are particularly rich in detail: he did not just copy literary models but was able to play with them because of his personal knowledge of games. ${ }^{74} \mathrm{He}$ started his career as a preacher in Antioch, which still had a lively tradition of Olympic games during (and after) his lifetime, so even if it would have been bad for his reputation as a priest to attend these games, he may well have visited them in his youth, and was able to hear about the games from eyewitnesses. ${ }^{75}$ John Chrysostom twice uses the image of a herald summoning the assembled people to identify potential participants as slaves. "Tell me, I invite you, does the herald at the Olympic contests not stand shouting with a loud and mighty voice "whether someone speaks against this man', saying 'no slave, no thief, no one of wicked manners'." "When all have sat down in the theater, the herald asks loudly

71 According to Aeschin. In Tim. 138 the Athenian law forbade slaves to take exercise and anoint themselves in the palaistras. This is confirmed by the gymnasiarchal law of Beroia (SEG 27.261, mid 2nd century BC). For a systematic treatment see Crowther 1992.

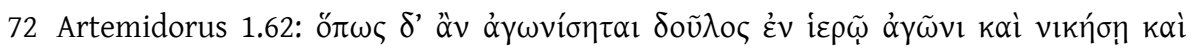

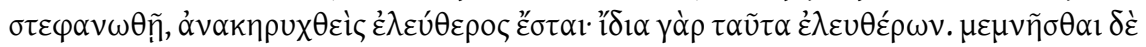

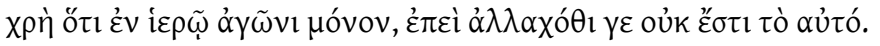

73 Crowther 1992: 36-37.

74 Koch 2007 collects all of John Chrysostom's agonistic metaphors.

75 Remijsen 2015: 95, 287.

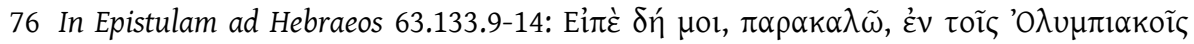

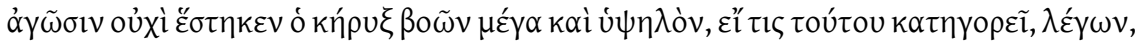

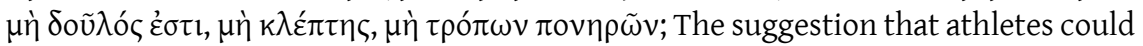
not be thieves or any other types of 'bad characters' is typically late-antique: cf. John 
whether someone will accuse this or that participant, so that he, having been cleared of the suspicion of slavery, can in this manner enter in the games."77 This suggests that the status of a participant was not checked upon registration, but that all athletes were in principle suspected of not belonging until the silence of the crowd cleared them of this suspicion. In the filled stadium, the herald announced with the words 'Does some-

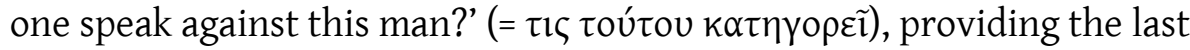
chance to bring a charge against one of the contenders.

Whereas John Chrysostom describes the crowd as having the final opportunity to incriminate an athlete, Pseudo-Dionysius suggests that it was usually fellow athletes who would identify slave-athletes. This author of a rhetorical handbook, perhaps from the early fourth century AD, discusses the penalties for athletes contravening the rules (i.e. technical, sports-related rules), which could comprise a fine but, more importantly, also corporal punishment. Agones were a rare context in which corporal punishment of free citizens was socially accepted; normally this type of punishment was reserved for slaves. In order to underline the contradiction between the free status of the athletes and the servile nature of their punishment, Pseudo-Dionysius writes: "If they notice a slave competing, they accuse him and exclude him as unworthy of the competition, while, as for themselves, they get a verdict of freedom from the athlothetai at the same time as they get the punishment of slaves for themselves."78

Cassian Instituta 5.12 (no athlete defiled by infamy, no slaves) from the early 5 th century AD. The summary of the Olympic oath at Paus. 5.24.9 contains only a clause that athletes had not sinned against the Olympics, not in general. Because of the association with freedom, John Chrysostom's addition can be connected to the Roman legal concept of infamia. Being a performer limited one's civil rights according to Roman law, in the same way as being a criminal or prostitute did. Although agones were distinguished from performances burdening someone with legal infamy from early on, only in late antiquity was the concept of infamy well-known enough in the East for an explicit formulation to arise that athletes could not be infamous to begin with. $\mathrm{Cf}$. Remijsen 2015: 323-24, 341-42.

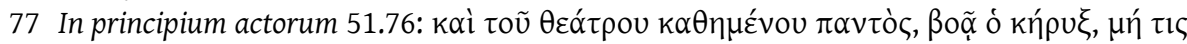

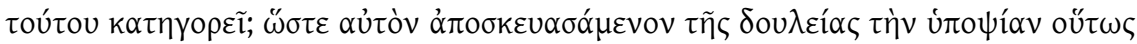

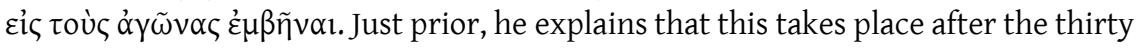
days of training preceding the games.

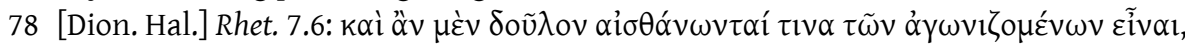

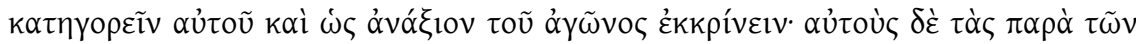




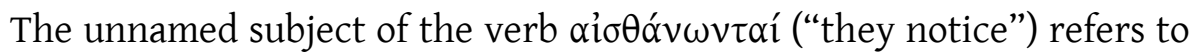
the athletes. Slaves were hence not caught by examiners, but by their

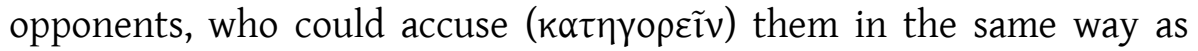
spectators could. The agonothetai, and not the hellanodikai or enkritai, are represented as the ultimate authorities in this procedure.

Pseudo-Dionysius thus confirms the existence of the reactive procedure described by John Chrysostom: the burden of unmasking participants as slaves did not lie with the organizers. All participants were treated as innocent, until charged by a third party with the crime of being slaves pretending to be free. The organizers seem to have counted on the extensive field of fellow competitors, as well as on visitors in other capacities, to catch athletes who claimed to be someone they were not. For local competitors, this type of social control would have sufficed, as most spectators came from the same region. It would also have functioned for adult athletes from further away. Many poleis would be represented not by a single athlete, but by an entire delegation of athletes and other representatives, who could exert social control. Not all athletes, however, would have been accompanied by such a large delegation. This was especially true in the imperial period, when some competitors travelled from contest to contest and covered long distances. By this time, however, the milieu of travelling athletes had become close-knit: competitors knew each other well from other contests, and often belonged to the worldwide synod of travelling competitors. ${ }^{79}$ This is no doubt why Pseudo-Dionysius identifies the competitors as the most likely people to raise alarm about an individual without clear credentials. This reactive system did not require an additional and far more laborious systematic check of the status of all athletes upon registration.

The one group of competitors for whom a reactive procedure is most likely to have been insufficient is that of the younger athletes. Whereas

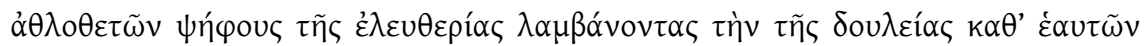

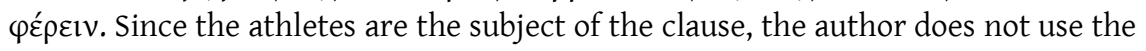
verb Ėkкpíveıv in a technical sense, but as a synonym of "the expulsion from both

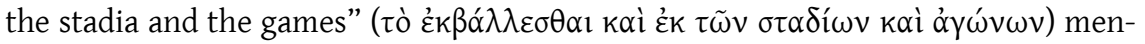
tioned previously.

79 See n. 118. 
an adult male was supposed to act independently, boys were not yet independent. A man with a well-trained slave boy could be hard to distinguish from a man with his son or ward ${ }^{80}$, all the more because the youngest athletes would not yet have become well-known among the other competitors. This may explain why Philostratus says that the free status of boys was checked systematically at the time of the enkrisis, which removed the need for an additional reactive procedure.

\section{THE REGISTRATION OF CITIZENSHIP}

\section{The declaration of fatherhood and citizenship in the imperial era}

Philostratus' Gymnasticus further explains that the judges enquired in each interview with a boy "whether he had a phyle and patris, whether he

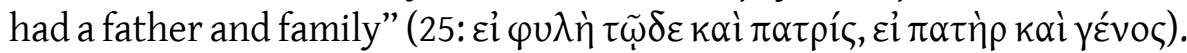
Taken out of context, Philostratus seems to be listing four additional criteria. The entire passage, however, is highly stylized: in the longer list of traits of athletes following this phrase, each trait is duplicated, often by the presentation of two opposites, or where this is not possible - as in this case - by two cognates. Each duo, therefore, represents one general criterion: the first can be summarized as 'citizenship', the second as 'family'. Evidently, boys were registered in the time of Philostratus with the name of their father and of their city; the author implies that these were criteria for admission. Since the two elements reflect the way in which victors were typically proclaimed by the herald ( $\mathrm{X}$, son of $\mathrm{Y}$, from polis $\mathrm{Z}$ ), this might be applicable to the adult athletes as well. This section will first look closer at the registration of the father and then turn to the question of citizenship. The discussion on the latter, more essential point

80 This remains difficult for modern scholars as well. The young boy Pyrrhos, whose athletic formation was paid for by the rich estate manager Zenon (P. Lond. VII 1941), is often identified as a slave trained to win money for his master (e.g. Golden 2008, 43), but can more safely be identified as an orphan of a client of Zenon's, and hence a free young man, like the other orphan supported by Zenon in PSI IV 418. See Clarysse \& Vandorpe 1995: 61-62. 
will focus on whether having a citizenship mattered. This does not involve a full geographical survey of which citizenships are recorded, since this would only document where athletics was practiced on a high level, but would offer no basis for reevaluating the underlying hypothesis that Greekness was defined in terms of citizenship. ${ }^{81}$

IvO 56, a fragmentary inscription from Olympia containing the rules for participation in the Sebasta in Naples, confirms Philostratus' information that the name of the father was registered for all contestants upon their arrival. Lines 19-22 read:

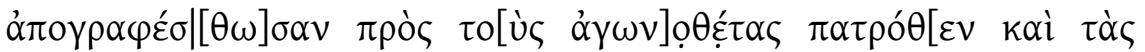

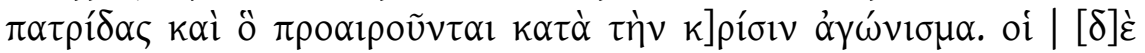

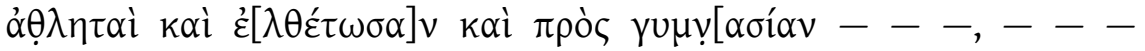

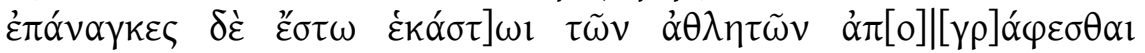

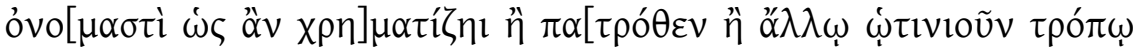

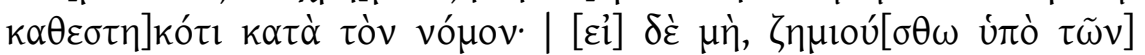

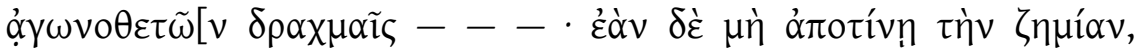
$\mu] \propto \sigma \tau \varepsilon l \gamma o u ́ \sigma \theta \omega$.

They shall register with the agonothetai with their father's name ... category competition (?). The athletes also [shall go?] to the training (or: the gymnasium?) ... and each of the athletes shall be registered with the name by which he is officially known, whether with his fa[ther's name or in whichever other way establ]ished by law. If someone does not do this, he shall be fined by the agonothetai ... shall be whipped.

I refrain from translating too much of the restored text between brackets, as these are merely suggestions. The remaining fragments confirm, however, the latter criterion of Philostratus for another major agon of the imperial age: the organizers of the Sebasta in Naples required athletes to enter the games under the name by which they were officially known, which included the name of their father. Athletes could even be fined for

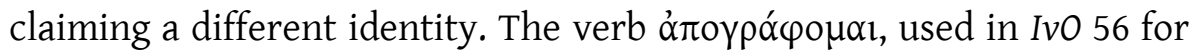


the act of registering, is also used for the registration procedure at Olympia in a rhetorical composition for educational purposes from the later fourth or even fifth century AD. ${ }^{82}$

The father's name was a traditional part of a person's full name in the Greek language, so it is not surprising that once a registration procedure was established, this information was expected from all athletes. But that does not mean that the procedure for adults was exactly the same as that for boys. Whereas for adult athletes, it would just have been a matter of declaring their official name, for boy athletes the identification of the father or another adult family member had an additional reason, which explains why Philostratus presents it as a criterion for admission. Adult athletes could perform legal and sacral acts themselves. At the Olympics, this included for example swearing at the statue of Zeus Horkios to commit no crime against the Olympic games. In the case of boys, who did not swear the oath themselves, an accompanying adult did it for him, as it was he who would potentially offer or accept bribes. ${ }^{83}$ This implies that boys had to be accompanied by an older male relative or a guardian.

IvO 56 does not only attest to the existence of a formal registration in Naples, but also documents a new criterion for admission, namely that an athlete could only compete if he registered before the deadline. Acceptable reasons for being late were sickness or an attack by bandits or

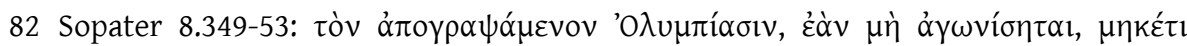

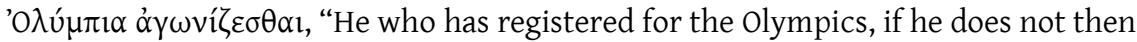
compete, can never compete at the Olympics again." This line comes from a selection of exemplary compositions on stock themes under various headings, which reflect the rules with which a student should engage in the exercise. Under the above heading, Sopater discusses the situation of a hypothetical athlete who had registered for the Olympic games, but went home before the competition started when he heard that his city was at war, and after winning the war, wanted to register at Olympia for a second time, but was not allowed to do so.

83 Paus. 5.24.9-10 explains that the same oath was sworn by the athletes' fathers, brothers, and trainers. A good illustration that bribing by family members was a real problem is P.Oxy. LXXIV 5209 (AD 267), a papyrus contract between the father of one boy wrestler and the two guardians of another stipulating both the sum the father would pay to the guardians when the latter boy lost on purpose and the fine the latter would pay to the former if he did not lose. 


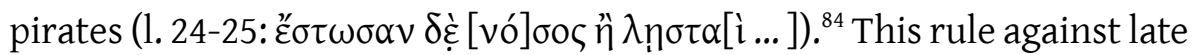
arrival is known from Olympia as well. According to Pausanias, one of the Zanes-statues (i.e. statues of Zeus paid for by athletes punished for a misdemeanor) was constructed by a certain Apollonios after the games of $\mathrm{AD}$ 93. "He did not arrive by the prescribed time, and the Eleans, if they followed their rule, had no option but to exclude him from the games." 85 The prescribed time was 30 days before the start of the Olympics. During this period the athletes trained together under the supervision of the hellanodikai in the old gymnasium at Elis. ${ }^{86}$ Apollonios blamed his delay on the wind, but Herakleides, a fellow Alexandrian who had traveled a similar route, knew better. "He showed that Apollonios was late because he had been picking up some money at the Ionian games. In these circumstances the Eleans shut out Apollonios from the games along with any other boxer who came after the prescribed time." ${ }^{87}$ Being late was apparently not a major offence: in this anecdote, several athletes did it, and would have gotten away with it if they had given a convincing reason, as they could in Naples. Although Apollonios' disrespect for the deadline resulted in an expulsion, it was not so offensive that the Eleans

84 It is possible that exceptions could be made if not enough athletes presented themselves. Heliod. Aeth. 4.2 describes the situation in which only one athlete presented himself for the race-in-armor of the Pythian games - he was so impressive that he terrified the competition - and that the herald at his request invited last-minute opponents to run against him. It is impossible to confirm, however, whether the situation in this novel represented contemporary reality.

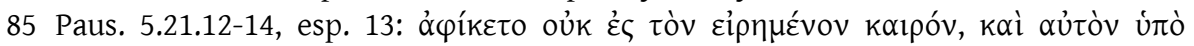

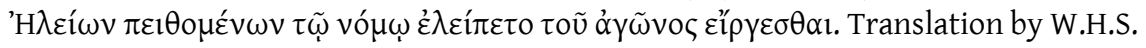
Jones \& H.A. Ormerod (LCL 188).

86 Philostr. VA 5.43 (30 days); Paus. 6.23 (the 'old gymnasion'). According to John Chrys-

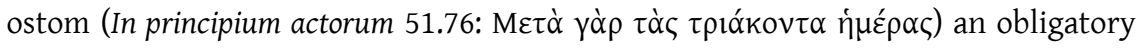
training of thirty days likewise existed for the Olympics games of Antioch. The editors of IvO 56 suggest a preparation period of 30 days for Naples for a gap in 1. 19.

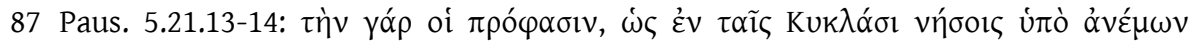

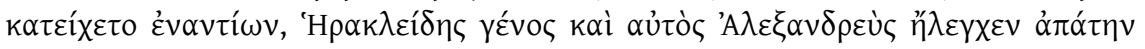

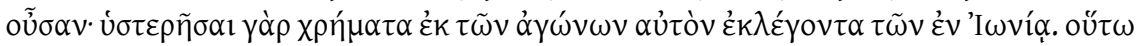

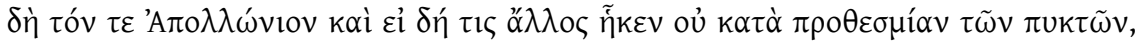

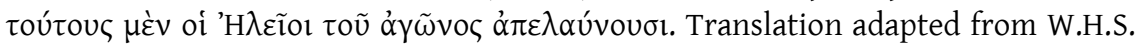
Jones \& H.A. Ormerod (LCL 188). 
requested him to pay for a statue: this fine he paid for beating up Herakleides in his frustration about the missed opportunity.

When this deadline was introduced is unclear. IvO 56 has as terminus post quem the foundation of the Sebasta in $2 \mathrm{AD}$, but the inscription may be as late as the second century. ${ }^{88}$ This makes the anecdote about Apollonios in AD 93 the earliest datable instance for the deadline. An inscription from Amphipolis shows that a registration upon arrival can be traced back at least to the second century $\mathrm{BC}$, though without the specification of a deadline. In the gymnasiarchical law, following rule was included: "And let the gymnasiarchs of the cities of Macedonia register $(\alpha \dot{\pi} \sigma \rho \rho \alpha \varphi \varepsilon \sigma \theta \omega \sigma \alpha v)$ in the city where they disembark for the first time the athletes who arrive in order to take part in the games, interrogating them for which event ( $\dot{\alpha} \theta \lambda \eta \mu \alpha ́ \tau \omega \nu)$ they arrive, and let them transmit the document to the priest and to the gymnasiarch appointed for the games having a crown as a prize." 89

There must of course have been a far longer tradition of athletes coming early in order to scout the competition. Already in the late archaic period, it was possible to have a victory "without dust" ('́kovııí), meaning that one of the competitors seemed invincible before the games had started, leading his opponents to withdraw timely. ${ }^{90}$ One must distinguish, however, between informal practices and the official introduction of a one-month preparation period and a registration deadline. ${ }^{91}$ Most likely, the traditional self-regulating system stopped being effective at some point because of the permanent increase in participants, which led to more formal regulations. In an agonistic landscape with many interesting opportunities for athletes, an obligatory stay of 30 days before the games could be used by the organizers to underline the special status of

88 SEG 58.411 dates it to the second century.

89 Hatzopoulos 1996: I 410 (translation), II nr. 16 (Greek).

90 For the term see Decker 1996. The earliest attestation is Ebert 1972: nr. 9 (a late 6thcentury BC inscription on a jumping weight). See also Ebert 1972: nr. 37 1. 5, for an attestation of a 'dustless' Pythian victory for the famous Theogenes (early 5th century BC).

91 Already Gardiner 1910: 202 acknowledged that the obligatory month of training was introduced after the classical period. 
their contests and the presence of the competitors and their entourage could, moreover, stimulate economic exchange in their city.

Now it has been established, at least for the imperial period, that the registration of participants with their official name was a standard practice, that competitors were only eligible if they arrived in time for the preparatory training and that boys had to be accompanied by an adult, we need to turn to the question of citizenship. Philostratus mentioned family and polis for the boys, and the registration of the former can be extended for all athletes on the basis of IvO 56. Unfortunately, the preserved fragments of this inscription do not confirm that citizenship was equally recorded. The suggestion of the editors to supply the word $\pi \alpha \tau p i ́ \varsigma$ on 1.20 is reasonable, however. The polis too was central to identity in the ancient world, and for athletes in particular, as the announcement of their polis by the herald shows. ${ }^{92}$ For Olympia, there is good evidence that the polis was recorded systematically in the imperial era. The list of Olympic stadion victors shows that athletes are consistently known as citizens of a polis in this period. Of all imperial-age athletes on this list which stops in AD 217 - there is only one exception: Stephanos the Cappadocian in AD 97. Even this may be an error: on the basis of a more complete Armenian manuscript of the list, we know that some information was lost during a late redaction, in particular when the original entry included both a polis and a region. ${ }^{93}$ Caesarea, the main city of Cappadocia, would have required specification of the region, as Caesarea was a common city name and, in the first century $\mathrm{AD}$, the more famous Caesarea was the one in Palestine.

The main question is not, however, whether citizenship was registered, but whether the wrong citizenship or the lack of one could be a criterion for exclusion. The most explicit evidence can be found in another late-antique text related to rhetorical training. A popular handbook for this type of training was a second-century work called De statis

92 See e.g. Mann 2001: esp. 25.

93 See Christesen \& Martirosova-Torlone 2006: 40-55 for the textual history of the list and 58 for a table with shortened geographical identifiers of athletes in the Greek manuscript. There are two cases where the polis is known only from the Armenian manuscript but the region is recorded in both: for 252 BC Xenophanes of (Amphissa in) Aetolia and for $168 \mathrm{BC}$ Aristandros of (Antissa on) Lesbos. 
by Hermogenes. This theoretical treatise categorized argumentative strategies and became particularly popular with teachers of rhetoric of the fourth and fifth centuries. They made their students acquainted with Hermogenes' argumentation strategies by means of stereotypical exercises about stock themes, which did not relate to contemporary legal proceedings, but to an imagined classical Greece. The commentaries on Hermogenes' De statis by Sopater, Syrianus and Marcellinus contain examples of themes employed for the discussion and training of each of Hermogenes' categories. Twice in these commentaries, the authors illustrate a particular argumentative strategy as follows: "As for instance the

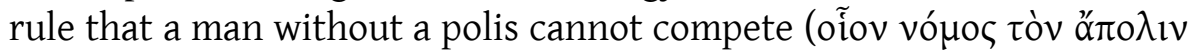

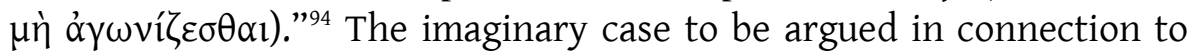
this rule was whether an Athenian living in exile was indeed without citizenship. The longer commentary starts with the following situation:

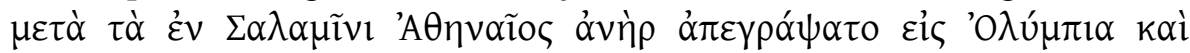
$\kappa \omega \lambda \cup ́ \varepsilon \tau \alpha 1$, "After the battle at Salamis an Athenian man has registered at Olympia and is refused."

These late-antique rhetorical exercises clearly imagine that athletes were formally registered with their citizenship on a list of competitors before the start of the competition, and that the lack of citizenship could be grounds for exclusion from the games. As the Olympic games came to an end only in the early fifth century AD, ${ }^{95}$ this idea may have been based on the contemporary situation. Although I am unaware of any other explicit formulation of this idea that an athlete could not be apolis, such a rule would be in line with what Philostratus says about the admission of boys, with the consistent record of citizenships of athletes in the imperial era and with the verifiable existence of a registration process requiring identification according to the law from at least the first century AD onward. It seems therefore reasonable to postulate the existence of this rule that all athletes had to be citizens of a city for the entire imperial period. Is it reasonable, however, to extend this to the preceding centuries? The Amphipolis inscription only specifies the registration of the

94 Syriani, Sopatri et Marcellini scholia ad Hermogenis Status 4.534.18-28 (attributed to the three commentators jointly) and 4.546.25-29 (attributed to Syrianus).

95 Remijsen 2015: 164-69. 
event, not of the citizenship of arriving athletes. If the rule and the registration procedure could be traced back to the first clear demonstrations of Greekness at the major agones around $476 \mathrm{BC}$, the advocates of an exclusive policy would have a reasonable basis for connecting ethnicity with citizenship.

\section{Registration of citizenship before the Roman era?}

Most athletes recorded in inscriptions and victor lists of the classical and Hellenistic periods are identified with both the name of their father and with their polis, as they were in the Roman period. The case for this being the consequence of an equivalent rule, however, is rather weak. While we know of only one exception in the last 300 years of the list of Olympic stadion victors, the number of athletes from the preceding period for whom no polis is known is clearly higher: there are 14 exceptions in the period from the seventh to the second century $\mathrm{BC}$, with at least one exception in each century, and as many as seven examples in the third century. ${ }^{96}$ It is difficult for all 14 athletes identified with a region but not with a polis to be explained away as manuscript omissions, because in most cases in which the Greek version contains less information than the Armenian, it is the region that was left out, not the city. ${ }^{97}$ Moreover, papyrus fragments from similar lists, copied around circa AD 200, confirm

96 Five victors were listed as Thessalians (648: Kraxilas, 524: Menandros; 460: Torymmas; 436: Theopompos; 256: Hippokrates), three as Macedonians (328: Kliton, 292288: Antigonos, 268: Seleukos, 264: Bilistiche), three as Aetolians (252: Xenophanes; 240: Eraton, 200: Pyrrhias), one as a Boeotian (196: Mikion) and one as Epirote (136: Antipatros). Two of these, Hippokrates and Bilistiche, are known only via the Armenian manuscript.

97 See n. 93. A geographical identification of the polis is certainly removed from the Greek manuscript in the following cases: for 204 BC Herakleides of Salamis (on Cyprus); for 184 BC Hippostratos of Seleuceia (in Pieria); for 92 BC Protophanes of Magnesia (on the Maeander); for 36 BC Skamandros of Alexandria (in the Troad); for AD 13 Diophanes of Prousa (by Mt. Olympus); for AD 189 Magnos (a Libian) of Cyrene. 
that these exceptions resulted from a deliberate habit of regional (as opposed to polis) identification. ${ }^{98}$ Victory epigrams and epigraphic victor lists for other contests, such as the Panathenaia, likewise document this occasional practice of regional identification, in particular in the Hellenistic period..$^{99}$ This suggests that declaring one's polis as a victor was in this period a matter of personal preference.

For some cases in which the athletes are identified with a region instead of a polis one could perhaps argue that the regional identification represents an alternative 'citizenship' - and that these are therefore not real exceptions - especially when they coincide with a strong league in that region or with monarchic rule. This argument does not work for all cases, however. Whereas the identification of victors as Aetolians in the third century BC coincides with the early-Hellenistic heyday of their

98 P.Oxy. I 12, Col. V, 11. 15-16 (dated paleographically to AD 200-250) records for 328 BC Kriton the Macedonian, confirming the lack of the city in the later manuscript tradition of the stadion victor list, though suggesting a mistake in the spelling of the first name in the latter. P.Oxy. XVII 2082, fr. 4, which lists Olympic victors in all disciplines, has two Boeotians without city for 296 BC (1l. 22-23; 1. 27) as well as a Thessalian without a city (11. 36-37). A further piece of the same papyrus (composed of fragments 6 and 7) presumably covered $264 \mathrm{BC}$ and names two further winners as Thessalians, of which the latter without a polis (1. 5), and one Macedonian woman connected to a Ptolemy (1l. 6-8), whose name is lost. This victor in chariot race for foals must be Belistiche, who is also mentioned in the Armenian manuscript of Eusebius' victor list.

99 Epigrams: e.g. Ebert 1972: nr. 30 (Isthmian victor identified as Cretan, late 5th century BC?), nr. 54 (Isthmian and Pythian victor identified as Phocian, ca. $300 \mathrm{BC}$ ), nr. 55 (= IAG 33, Olympic victor identified as Arcadian, ca. 300 BC) and nr. 68 (Olympic and Nemean victor identified as from the Troad, late 3rd century BC?), all without identification of a polis. In Posidippus' Hippika (early 3rd century BC), regions (8 times) are more often named than poleis (3 times): Ep. 71, 78, 82, 83, 84, 85, 87 and 88 all mention Thessaly or Macedonia (once referred to as the area Eordaia). Victor lists: in the Panathenaic victor lists from ca. 200-180 we find three Boeotians (IG II ${ }^{2}$ 2313, col. I 3, col. II 18; 2314, col. I 9-11) and one Epirote (IG II ${ }^{2} 2313$, col. II 24). Another particularly interesting example is a victor list from the Basileia at Alexandria (SEG 27 1114), dated to 267 BC and listing - besides four athletes identified with a polis - four Macedonians, six Thracians, a Thessalian and a Boeotian, who were presumably all military settlers in Egypt. For a commentary see Koenen 1977: esp. 1928. 
league, and the Boeotian victors can possibly be connected to the particular agonistic interest of the Hellenistic Boeotian league, such a chronological link is difficult to find for the Thessalians, who are well attested among these victors without a specified polis. ${ }^{100}$ The Achaean league, moreover, which had a particularly important political role in the third and second century $\mathrm{BC}$, is conspicuously absent. ${ }^{101}$ This league did not represent a region with a strong identity, whereas the regions most athletes without a polis identified with, such as Thessaly or Boeotia, typically had a strong regional tradition. It is this regional identity, not their citizenship, that victors wanted to underline. The lack of a link with citizenship is even clearer in the case of monarchies. An Epirote won in 136 $\mathrm{BC}$, that is when the Romans had already put an end to the Epirote monarchy. Macedonia was united under the Antigonid dynasty in the third century, when this identifier is best attested for victors, but many of the 'Macedonian' victors actually lived in Ptolemaic Egypt. Families who migrated from traditional areas of Hellas to Ptolemaic Egypt and were settled on farmland along the Nile were in fact truly apolis until Septimius Severus granted polis rights to the provincial cities of Egypt. ${ }^{102}$

There are further indications that we cannot project onto the classical or early Hellenistic period the imperial-age rule that no athlete could be apolis. Even if Sopater thought of banishment as an impediment to par-

100 The recorded Boeotian victors are all from the third and second centuries BC. Although the Boeotian league was reconstituted after 338, it never regained the predominant position it had in the classical period (cf. Funke 1997: 735). This only goes for its role on the international stage, however; locally it was particularly active in the development of new agones, which shows that athletics was an important outlet for Boeotian identity (cf. Parker 2004: 15). Victors are recorded as Thessalians from the seventh until the third century BC. Their league was a rather loose confederacy, with which the main noble families were not always cooperating (cf. Beck 2002: 44850). Most coins of the league date from the second century $\mathrm{BC}$, when Thessalian identity is no longer attested in the victory list. For the prominence of Thessalian identity among Hellenistic agonistic epigrams, see Scharff 2016.

101 See Freitag 2013 for the activities of the Aetolian and Achaean leagues at the 'Panhellenic' sanctuaries in the third and second centuries BC.

102 The most famous examples are of course the Ptolemies themselves and Belistiche. The same goes for the military settlers of SEG 27.1114 (see n. 98). For their lack of citizenship see Remijsen 2014: 354-56. 
ticipation at Olympia, this was not yet perceived as a problem by Herodotus. ${ }^{103} \mathrm{~A}$ whole series of anecdotes illustrates that it was in fact perfectly possible in the fifth or fourth century BC to gain a victory for a city in which one did not have citizen rights. The most famous case of a victory proclaimed with the 'wrong' city is that of the Spartan Lichas, whose team of horses participated in the Olympics of $420 \mathrm{BC}$ and was proclaimed as a team of either Thebes or the Boeotian civic body. Elis had excluded the Spartans from the festival because they had violated the sacred truce - here we see the use of a short list of expressly excluded cities rather than a long one of included cities. When Lichas after the proclamation came up and crowned the charioteer in order to identify himself publicly as the owner, the Eleans got angry and beat him up. ${ }^{104}$

In the work of Pausanias we find many other relevant anecdotes. Writing in the second century AD, Pausanias was used to athletes recording their citizenship according to the legal reality, so a change of polis within an athlete's career struck him as something remarkable that needed to be explained. ${ }^{105}$ In this way, he has preserved many anecdotes from the classical era concerning athletes who were bribed to have themselves proclaimed as athletes from a different city than their home town. ${ }^{106}$ The Sicilian tyrants seem to have specialized in this way of buying extra honor for themselves and the polis Syracuse. More illuminating than the famous case of Astylos and the less well-known case of Dikon is

103 Hdt. 6.103: Kimon was proclaimed with his own name after the first victory during his exile, but attributed the second to Peisistratos. Herodotus seems to have found nothing remarkable about the polis mentioned in these proclamations, as he gives no information on it.

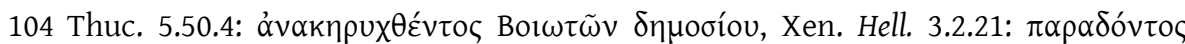

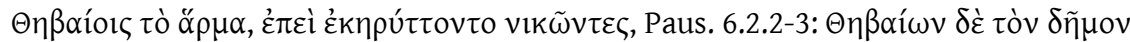

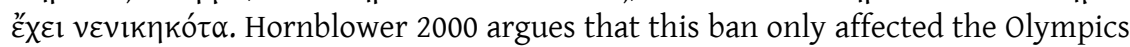
of $420 \mathrm{BC}$.

105 Thus when discussing monuments for the Ptolemies, Pausanias explicitly notes that they called themselves Macedonians, adding as a correction at 6.3.1 that Ptolemy I was in fact king of Egypt, and at 10.7.8 explaining that the kings of Egypt were indeed Macedonians.

106 Pausanias also narrates Olympic bribery scandals for the Roman period $(5.21 .9,15-$ 17), but these follow a different pattern: they involve one of the parties bribing the other to secure victory and not, as in the classical bribing scandals, a city paying a victor to announce himself in a particular way. 
the story of the boy athlete Antipater from Miletus: "Men of Syracuse, who were bringing a sacrifice from Dionysius to Olympia, tried to bribe the father of Antipater to have his son proclaimed as a Syracusan. But Antipater, thinking naught of the tyrant's gifts, proclaimed himself a Milesian." ${ }^{107}$ This shows that the Syracusans did not contact and 'naturalize' athletes before the Olympics, but approached the main contenders for the crown on the spot - this was of course more efficient (and hence cheaper) than bribing all possible victors. The case of Antipater does not represent an exceptional situation, as the Sicilian tyrants were not the only ambitious men to fall back on ad hoc bribing as a method for success. In 380, the Cretan Sotadas had himself proclaimed as an Ephesian after being offered a bribe. ${ }^{108}$ Such anecdotes indicate that the herald did not get his information on the victor from a register made upon the arrival of the athletes, but from the victor himself. ${ }^{109}$ Wolicki observed that the victor could in this period decide to have each of the elements of his identification changed: his own name, that of his father and his city. ${ }^{110}$

The only classical case in which Pausanias does not speak of a victor 'being announced' as being from a city (mostly using the verb $\alpha v \alpha \gamma o \rho \varepsilon v ́(\omega)$, but of actually receiving politeia, is that of Ergoteles, who came from Cnossus but was expelled from this city by an adverse political party and hence moved to Himera. ${ }^{111}$ Similar political motivations were behind the proclamation of Dorieus and Peisirodoros (son and grandson of the famous Rhodian athlete Diagoras) as victors of Thurioi. ${ }^{112}$ In both cases we cannot be certain that the athletes formally received citizenship of their new homes before their victory. Sharing the glory of an athletic victory with a desired new fatherland could indeed constitute a

107 Paus. 6.13.1 (Astylos); 6.3.11 (Dikon). Paus. 6.2.6: $\Sigma v \rho \alpha \kappa o \sigma i ́ \omega v \delta \dot{\varepsilon} \alpha{ }^{\prime} v \delta \rho \varepsilon \varsigma, \alpha^{\prime} \gamma o v \tau \varepsilon \varsigma \grave{\varepsilon} \varsigma$

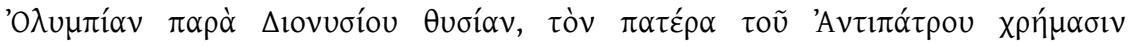

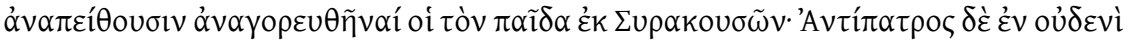

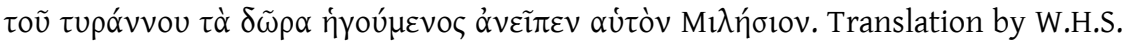
Jones (LCL 272).

108 Paus. 6.18.6.

109 Roos 1985: 164 likewise accepts this as evidence that there was no registration of the origin of the participants before the event.

110 Wolicki 2002: 78-79.

111 Paus. 6.4.11.

112 Paus. 6.7.4. 
ground for the subsequent award of citizenship. An inscription from circa 300 BC records the grant of citizenship to the boy athlete Athenodoros, who was living in Ephesus as a foreigner, only after he had himself proclaimed as an Ephesian at the Nemean games. ${ }^{113}$

The registration of some victors with their region but without their polis on official victor lists from the archaic period until the first century $\mathrm{BC}$, the similar commemoration of victors identified solely by region in classical and Hellenistic epigrams, the bribing scandals involving the announcement of a victor as competing for a city of which he was not a citizen and the early Hellenistic case of Athenodoros receiving Ephesian citizenship only after he was announced as Ephesian at Nemea all indicate that before the Roman era, the citizenship of athletes was not registered or scrutinized by the authorities of major agones, including the Olympics. According to Gorgias (late fifth century BC), at the start of the

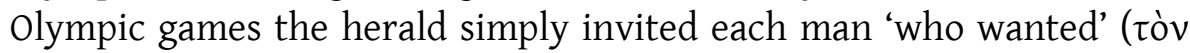

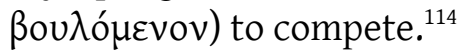

\section{The purpose of the registration procedure}

It has thus far been established that the registration of athletes with their official name and citizenship was introduced in the Roman era, but was not in place in the classical or early Hellenistic period. The last question to be answered in this section is why this procedure was introduced. If one assumes the existence of an exclusive ethnic policy, this could have been a reaction to a greater need to check systematically whether they were Greeks. None of the imperial-age sources on citizenship, however, not even Philostratus who uses twice as many words as necessary, speak of ethnos or of being Greek in connected to this registration. There is evidence that a lack of citizenship could be ground for exclusion, but not that it was possible to have the 'wrong' citizenship. This is different for

113 I.Eph. 1415.

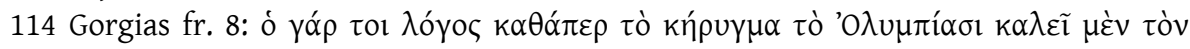

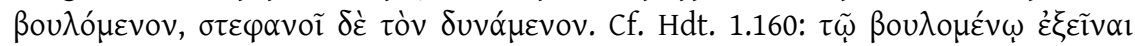

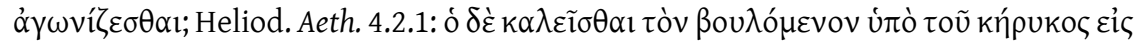

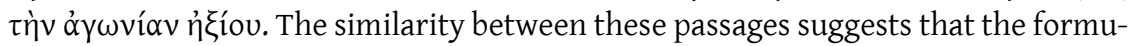

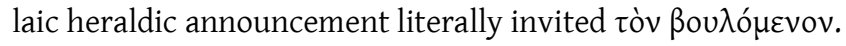


the Panhellenion, a contemporary institution that did make use of Greek ethnicity as a criterion for admission, and had a considerably smaller geographical scope than the major agones. ${ }^{115}$ This suggests that there must be a better explanation for this change in agonistic procedures. I will argue that it can be better understood as a logical step in a process of bureaucratization.

Throughout the history of the agones, the field of competitors became larger and more varied. The expansion of the agonistic circuit was particularly clear in the third and second centuries BC: at that time athletics was introduced in most cities in the new Hellenistic kingdoms and new agones in these areas gave local athletes ample opportunity to obtain experience and to dream of successes on an even higher level. Epigraphic dossiers like that concerning the introduction of the Leukophryenia at Magnesia-on-the-Meander in $208 \mathrm{BC}$ document the frantic activity of theoroi in this period. ${ }^{116}$ One point negotiated by Hellenistic cities with as many other cities as possible was whether these cities acknowledged the stephanitic status of a contest and therefore agreed to grant privileges to the victors. After the second century BC, however, there is little evidence for such diplomatic activities. The network of cities involved in agones had simply become too large for a system based solely on bilateral agreements between individual cities. ${ }^{117}$ Already in the second century $\mathrm{BC}$, therefore, many poleis had begun to reach out to the authority of Rome. In the imperial period, this had become standard: a polis with a new contest asked Rome to acknowledge its status. Likewise, the athletes no longer relied on their city to guarantee the privileges related to victories at contests with an elevated status. From the first century BC on they were cooperating in a supra-regional synod, which negotiated directly with Rome. ${ }^{118}$ In the second century AD, this synod had headquar-

115 Romeo 2002: 21-40.

116 Rigsby 1996: 179-279 collects the whole dossier. For a discussion of the broader tendency, and a list of Hellenistic agones negotiating their status, see Parker 2004: esp. 18-22.

117 For the introduction of 'stephanitic' as a formal status and its further development in the late Hellenistic period see Remijsen 2011.

118 For the development of this synod see Fauconnier 2016. 
ters in Rome with officials who were well connected to the court. Imperial supervision introduced a higher degree of uniformity to the agonistic circuit. In the early second century, Trajan and Hadrian seem to have been particularly active in this field; both issued precise regulations about the privileges of victors, after more general regulations concerning the status of athletes had already been issued by previous emperors. ${ }^{119}$

Central to all these negotiations - whether with poleis or with the Roman court - were the privileges which athletes could claim in their own cities on the grounds of their victories in specific contests. These were not only special honors, such as front seats in the theater, but also substantial economic benefits, including the exemption from taxes such as civic liturgies and even monthly pensions in cash. It is therefore not a coincidence that the earliest evidence for a formal registration of athletes, a second-century BC inscription from Amphipolis, makes this obligatory only for stephanitic games. As more agones were founded, ever more athletes enjoyed agonistic successes and for those cities with many victors the privileges could represent a strain on the civic finances - and indirectly on the cities' ability to pay taxes. It was therefore in the interest of the Roman authorities to obtain closer control over these privileges, by supporting the regularization and uniformization of agonistic procedures. ${ }^{120}$ The culmination of Roman bureaucracy at the games can best be seen in the papyrological evidence of the second and third century AD. On the basis of the preserved document types, Slater describes how victors of games with eiselastic status - the highest possible status, which had to be acknowledged by the Roman court and gave victors the right to a monthly pension in cash - had to deal with a series of different

119 See Plin. Ep. 10.118-19, for his exchange with Trajan on the date from which the allowances for stephanitic victors were to be calculated; and Petzl \& Schwertheim 2006 for three letters of Hadrian dealing with the festival network. Dig. 3.2.4.pr. excludes athletes from the limitations for entertainers stipulated in Roman law. This text refers to the opinions of Sabinus and Cassius, jurists active in the reign of Tiberius. Pap.Agon. 1, ll. 2 contains a letter of Claudius regarding the privileges for artists - who were competing in agones in the same way as athletes - and refers to preexisting privileges granted by Augustus. See also Suet. Aug. 45.

120 Remijsen 2015: 208-13, 230-37; Slater 2015: 149-54. 
forms before they would be paid out their pension. ${ }^{121}$ One of the necessary documents was a certificate by the organizing city, given to each victor to hand over to the administration in his own city, which contained official confirmation of his victory; it mentions his full name, the name of the contest, the discipline, and the date of the victory. This certificate was formally addressed to the city of the victor, its magistrates, council and people. Although we have only one example of this document type, namely the certificate issued in the 260s by an Alexandrian official for Marcus Aurelius Horion of Hermopolis, victor at the Alexandrian Olympia ${ }^{122}$ it seems safe to assume that every agon issued such certificates for each individual victor in the third century AD, and presumably already before that. This is, therefore, a context in which the precise identification of competitors, exactly as they were known to the polis administration, mattered. These administrative documents are more or less contemporary to Philostratus' Gymnasticus and therefore offer the primary background against which Philostratus' statement about a check of citizenship needs to be understood - rather than Herodotus' anecdote on Greekness, by now 700 years old.

The Roman administration also created paperwork that would have enabled formal identification at the games. In the classical or Hellenistic period, it would have been difficult for an athlete to prove his citizenship. Locally, that would not have been an issue, because ancient cities did have archives, and, in order to enjoy the rights and duties of a citizen at least in larger communities, men needed to be enrolled on official lists when they reached the age of majority. Such procedures used locally to identify citizens, however, could not easily be transplanted to an 'international' context such as the games. In case of a dispute, one can imagine that theoroi were asked to vouch for an athlete ${ }^{123}$, but with the increasing number of participants, one can also imagine that delegations from some cities far removed from Olympia ended up being very small. A functional Olympic bureaucracy is inconceivable before some kind of administrative standardization took place across the whole catchment area of the 
games. This is exactly what seems to have happened in the first century $\mathrm{BC}$ under Roman government.

Examples of more widely recognizable identification documents that could have been presented can again be found among the administrative papyri. In the course of the Hellenistic period the ephebate spread across the eastern Mediterranean as an institutionalized program for the training of future citizens. By the late second century BC, most poleis in the Greek cultural area seem to have had this institution, as did the provincial cities in Egypt. ${ }^{124}$ At this time, enrollment in the local gymnasia still seems to have been a paperless affair, as there are no Hellenistic papyri related to it. This changed under Roman government: because membership of the gymnasium had become ideologically linked to citizenship, they introduced supervision over the enrollment to make sure that only boys with the right status were accepted. In Roman Egypt, the enrollment of boys aged 13 or 14 on the list of the ephebes of the following year followed a procedure called the eiskrisis. The request for enrollment was formally made by the parents to a commission of officials headed by the exegetes (a municipal magistrate with important responsibilities in the government of the city). This commission examined whether the candidate fulfilled the conditions: namely, whether he was of the right age and whether his parents had citizenship. It is also often stated that the father had been an ephebe, which may or may not represent a separate condition. ${ }^{125}$ Once registered, each young man could get an excerpt from the ephebic list to prove his status. Such excerpts state the date of registration as an ephebe, give full information on the parents (father identified with name, patronymic, phyle, deme and age; mother identified with name, patronymic, status, age and guardian; archive where this was on record; type of marriage), as well as the name of the son and the year in which he was born, and end with an endorsement by a notary. ${ }^{126}$

Another document that competitors could have carried was their membership certificate of the synod of traveling athletes. A network of

124 For the Hellenistic ephebate see Kennell 2006 and Chankowski 2010.

125 For a full discussion of the eiskrisis and all evidence see Legras 1999: 151-79. For a new eiskrisis text see Galazzi \& Kramer 2014: 117-53.

126 Delia 1991: 71-72 gives a good overview of the document type. See Legras 1999: 152 for all references. 
local officials across the eastern Mediterranean was in regular contact with other stakeholders in the field traveling from agon to agon as well as with the headquarters in Rome, and maintained relatively uniform practices. Although the one extant copy of a membership certificate was made in Naples for Hermeinos, an athlete from the Egyptian town Hermopolis, we can assume that most athletes paid for membership to local representatives, as we can see in similar documents of the association of performing artists. ${ }^{127}$ These officials, therefore, were either already acquainted with the new member or could locally check whether the athlete was indeed who he claimed to be. With their membership certificate, the athletes acquired a means of identification which would have been widely recognized at the agones. Hermeinos certainly carried his certificate on his travels, for during games in Sardis, the local officials added a record of Hermeinos' role as a priest during these games to the original document.

The existence of these document types shows that by the first century $\mathrm{AD}$, the organizers of the games could reasonably expect athletes to supply some sort of formal document, when asked to do so. But it does not, of course, mean that athletes were also required to present these specific papers upon registration. Younger boy athletes may not yet have been enrolled in the ephebate. Some less professional athletes would not have joined the international synod, given that there was a membership fee. It seems more likely that an athlete during the registration process verbally declared who he was and of which city he had citizenship, and that official documentation was only requested when a doubt was raised. Since only a clear identification ensured a victor's access to privileges, lying was not to the advantage of the athletes. We may readily imagine,

127 The certificate for Hermeinos is Pap. Agon. 6 = P.Lond. III 1178 (AD 194). For similar documents of the thymelic synod of artists see e.g. Pap. Agon. 3 = P.Oxy. XXVII 2476, 11. 17-33 and Pap. Agon. 4 = P.Oxy. Hels. 25, 11. 22-30, all certificates for Egyptian residents signed by Egyptian residents. In the case of Hermeinos, the board of officials registering the new member at Naples probably had no need to check his identity, for the president of the association who signed the document was a native of Hermopolis just like the athlete in front of him and must have been personally acquainted with him. 
in other words, an essentially reactive control mechanism, as in the case of slavery.

\section{POLYBIUS ON THE GREEKNESS OF KLEITOMACHOS}

Thus far, this paper has shown how the known registration and admission procedures served to avoid irregularities in the youth categories, to exclude people with the legal status of slave and to create uniform procedures to avoid misuses and excesses with respect to agonistic privileges. It has been observed that citizenship was not scrutinized or registered until the Roman era and that the extant sources on agones do not make a connection between citizenship and ethnic identity. The plentiful evidence on admission and registration, in other words, offers no indication whatsoever that the general association between athletics and Hellenic identity, made by authors from the fifth century onward, resulted in an official and enduring ethnic policy at the major games.

That does, of course, not mean that athletic contests became wholly unconnected with issues of ethnic identification after the fifth century BC. Even if Greekness was not a principle at the very core of the ancient Olympic ideology that determined eligibility, the games continued to provide occasions for the expression of a resurging and constantly redefined Greek identity. A particularly interesting phase is the Hellenistic period, when the creation of large kingdoms which culturally presented themselves as Greek encouraged the formation of new conceptions of Hellenic identity. ${ }^{128}$ The crystallization of such ethnic feelings inspired, for example, two new festivals on the Greek peninsula devoted to Panhellenic victories: the Eleutheria at Plataea, commemorating the 479 victory, but founded circa $300 \mathrm{BC}$ or shortly before; and several decades later, the Soteria at Delphi, which commemorated the victory of the Greeks over the barbarian Gauls. ${ }^{129}$ At the same time, Greek culture rapidly spread to new areas. With the expansion of the catchment area of the Olympics, the odds of winning these games decreased for athletes

128 For an overview of different conceptions of Greek identity in this period see Burstein 2008.

129 Parker 2004: 19; Burstein 2008: 65. 
from the peninsula, so it is not surprising that occasionally these athletes held a grudge against successful contenders from newer areas. Similar ill feelings against Alexander I - whether historical or invented in retrospect as a propaganda tool - are what Herodotus conveys in the anecdote discussed at the beginning of this paper. Likewise, a grudge was apparently held in the late third century BC by the famous Theban champion Kleitomachos against an athlete from Egypt, who opposed him in the Olympic finals. This is described in a well-known passage of Polybius.

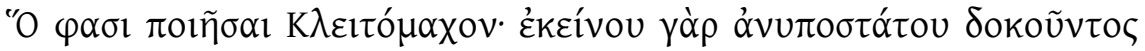

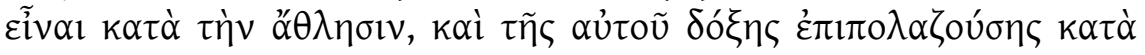

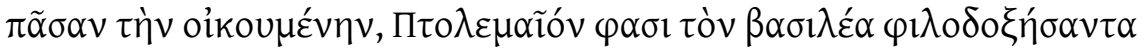

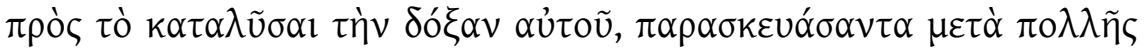

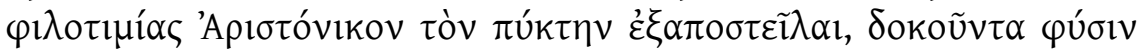

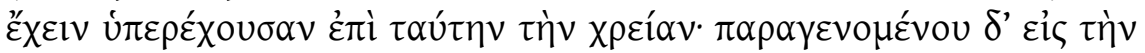

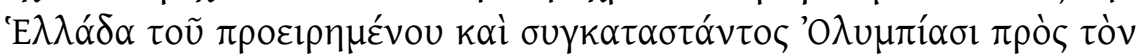

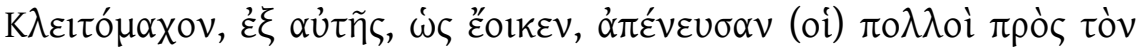

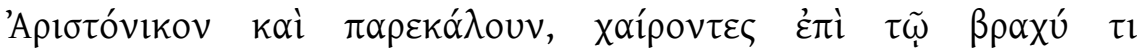

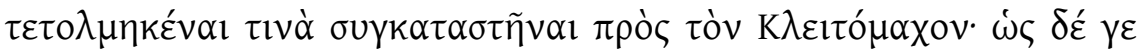

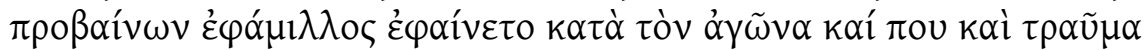

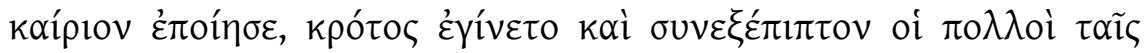

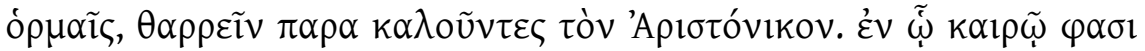

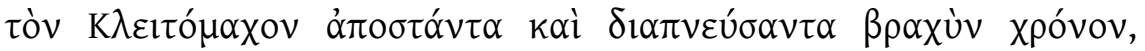

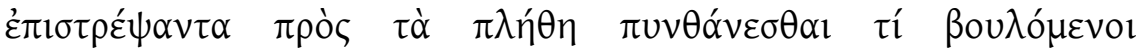

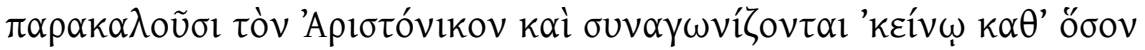

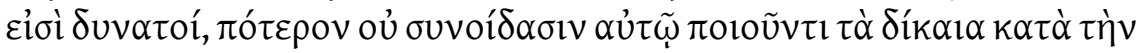

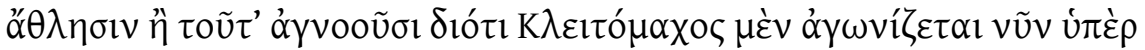

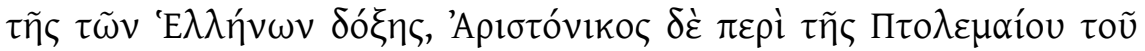

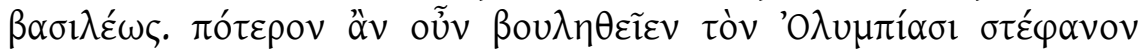

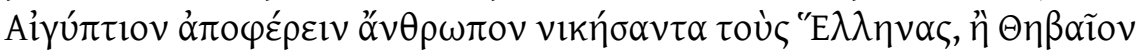

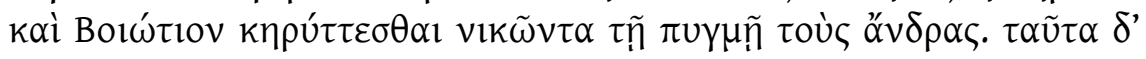

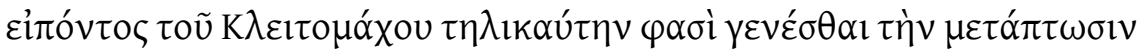

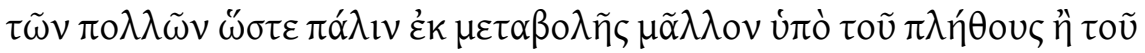

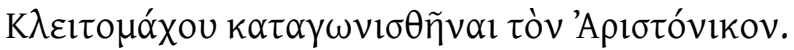


This was what Kleitomachos did, as it is told. He was considered to be a quite invincible boxer, and his fame had spread over the whole world, when Ptolemy, ambitious to destroy his reputation, trained with the greatest care and sent off the boxer Aristonikos, a man who seemed to have a remarkable natural gift for this sport. Upon this Aristonikos arriving in Greece and challenging Kleitomachos at Olympia, the crowd, it seems, at once took the part of the former and cheered him on, delighted to see that someone, once in a way at least, ventured to pit himself against Kleitomachos. And when, as the fight continued, he appeared to be his adversary's match, and once or twice landed a telling blow, there was applause, and the crowd became delirious with excitement, cheering on Aristonikos. At this time they say that Kleitomachos, after withdrawing for a few moments to recover his breath, turned to the crowd and asked them what they meant by cheering on Aristonikos and backing him up all they could. Did they not agree that he was doing well in the match, or were they not aware that he, Kleitomachos, was now fighting for the glory of Greece and Aristonikos for that of King Ptolemy? Would they prefer that an Egyptian subject defeated the Greeks and took the Olympian crown, or that a Theban and Boeotian was proclaimed by the herald as victor in the boxing for men? When Kleitomachos had spoken thus, they say there was such a change in the sentiment of the crowd that now all was reversed, and Aristonikos was beaten rather by the crowd than by Kleitomachos. $^{130}$

As with the Alexander anecdote, the meeting between Kleitomachos and Aristonikos can be accepted as historical. Kleitomachos was a famous athlete from the late third century. ${ }^{131}$ Pausanias (6.15.3) dates his first victory at Olympia, in pankration, to the 141st Olympiad (216 BC) and explains that he wanted to win both the pankration and the boxing in 212 $\mathrm{BC}$, but obtained a victory only in the latter discipline. Pausanias does not mention his opponent in the boxing, but this could well have been the Aristonikos mentioned by Polybius. The king supporting him in 212 would have been Ptolemy IV. Although his protégé's name ("excellent

130 Polyb. 27.9.2-13. Translation adapted from W.R. Patton (LCL 160).

131 Paus. 6.15.3-5, Anth.Pal. 9.588 (= Ebert 1972, nr. 67). 
victory") sounds almost too apropos for an athlete, there is no reason to assume that it was made up. The name is indeed attested for several members of the elite in Ptolemaic Egypt. ${ }^{132}$ The best candidate for identification with the athlete is Aristonikos, son of Aristonikos, who was proxenos at Delphi and eponymous priest in his later years. Like the boxer, he had a close connection with both the Ptolemaic court and a 'Panhellenic' sanctuary.

There are at the same time indications for embellishments in the anecdote. Ancient boxing did not have rounds, but featured a continuous fight ending when one of the parties gave up. There was, in other words, no obvious occasion for stepping back and holding a speech - though there may have been enough time for a snappy oneliner. The speech is, however, essential for the rhetorical strategy of Polybius. The story of the boxing final is told not for its own sake as a memorable event of the year 212 BC, but in the context of the Third Macedonian War fifty years later. Polybius did not approve of the fact that people in Hellas (meaning here the traditional poleis within the Antigonid Kingdom) had reacted positively to a preliminary victory of king Perseus. He tries to explain why they took the side of an undeserving monarch by interpreting this reaction as the spontaneous sympathy that crowds often develop for the weaker party in a conflict. Polybius suggests that the people would not have reacted in this way if they had been made to really think about it. ${ }^{133}$

132 In the period 240-160 BC (roughly the lifespan of the boxer), we know Aristonikoi in the Arsinoites and the Herakleopolites, who were probably royal farmers ( $P$. Cairo Zen. III 59372, 1. 3; P. Tebt. III 918 descr., col. 1, 1.11; SB III 6280,1. 13, 22), an Aristonikos son of Aristonikos as an Alexandrian proxenos at Delphi in the 180s (Syll. ${ }^{3} 585,1.140$ ) and as an eponymous priest of Alexander around the same time (cf. Clarysse \& van der Veken 1983: nr. 104 for 187-186 BC), and an Aristonikos taktomisthos (military rank) in P. Giss. I 2, col. 2, 1. 11 (173 BC).

133 Polyb. 27.10.2-3: "For if anyone had secured their attention, and asked them frankly if they really would wish to see the supreme power in so absolute a form fall into the hands of a single man and to experience the rule of an absolutely irresponsible monarch, I fancy they would very soon have come to their senses and, changing their tune, have undergone a complete revulsion of feeling. And if one had reminded them even briefly of all the hardships that the house of Macedon had inflicted on Greece, and of all the benefits she had derived from Roman rule, I fancy the reaction would have been most sudden and complete." Translation by W.R. Pat- 
This is where Kleitomachos and the Olympics come in. Taking a case from an agon suits the author's purpose particularly well because it puts both the fighting (always a good metaphor for war) and the crowd, whose behavior he wants to comment on, in the same physical space. At the same time, it is also a context from which he could expect his readers to recognize the feeling of sympathy for a lesser man. Polybius chose the match between these particular opponents, as these allowed him to elaborate his central political argument.

Ethnicity is secondary to politics in this passage. Polybius does not even mask the fact that Aristonikos could be seen as a Greek: he calls the athlete by his Greek name, Aristonikos. The proxenos at Delphi called Aristonikos, son of Aristonikos, with whom Kleitomachos' opponent might be identified, had Alexandrian citizenship. Elsewhere in his work (34.14.1-5), Polybius explains that one needs to distinguish between Egyptians, mercenaries and Alexandrian citizens. The latter, though they intermingled with the others, remembered the habits of the Hellenic community and had common roots. The above anecdote, however, was not about Aristonikos' blood. Kleitomachos did not question his opponent's right to be there, he just did not believe that this man deserved the support of the crowd, and this is linked to the different political situations in Egypt and Boetia. ${ }^{134}$ From the beginning, Aristonikos is presented by Polybius as a pawn of King Ptolemy, competing at Olympia because he was sent there, which implies that he was not gaining any personal honor. This idea is taken up in the speech of Kleitomachos: whereas Aristonikos is competing "for" ( $\pi \varepsilon \rho i$ í) the reputation of the king, Kleitomachos is competing "in defence of (úrźp) the reputation of the Hellenes." In the next sentence two words get a particular emphasis. The

ton (LCL 160). Polybius generally associates crowds and popular assemblies with uproar and irrationality. See Eckstein 1995: 136 (with a list of references) and 241, for a comparison with the popularity of Eumenes II of Pergamum (31.6.6), which Polybius found equally unjustified.

134 As we have seen, the normal procedure for complaints was petitioning the hellanodikai. We know from Pausanias (6.15.4-5) that Kleitomachos petitioned the hellanodikai in 212 BC, but on a completely different matter: as he wanted to compete in both boxing (the most dangerous sport with regard to injuries) and pankration, he requested, and was granted, that the pankration was for once programmed before the boxing. 
grammatically unnecessary noun öv $\theta \rho \omega \pi$ ov (litt. "human," but often used with a negative connotation, hence also used for slaves) is emphasized by being detached from Aiyútuc1ov. Polybius is hence not just talking about "an Egyptian," as in the translation of Paton, but about "an Egyptian subject." In the next clause, ơ $v \delta \rho \alpha \varsigma$ (litt. "men," with a positive connotation, as in the derived noun $\alpha v \delta \rho \varepsilon i ́ \alpha$, "manliness, bravery") on the surface identifies the age category in which the two athletes were competing, an unnecessary addition for understanding either the grammatical structure of the sentence or the context of the boxing match. Nevertheless, this word receives extra focus due to its final position in the sentence, which can only be explained by the contrast with óv $\theta \rho \omega \pi \mathrm{ov}$ : it is a contest for real men. This contrast between a subject and a real, independent man shows that the political situation was for Polybius the essential difference between a man from Egypt and one from Boeotia.

The rhetorical context makes it impossible to decide whether the ethnic tensions associated with Polybius' political message go back to a famous complaint by Kleitomachos or were added by Polybius, in whose lifetime Egypt was far less integrated in the Greek world than it had been in the third century. Whether historical or not, however, the story shows that Polybius, like Herodotus, considered Olympia a likely venue for the crystallization of such tensions. As evidence for the exclusion of nonGreeks at Olympia, however, it can again not be used: the anecdote does not contain a single indication that this rule existed. Against this background, the fact that Aristonikos was most likely an Alexandrian citizen from a high-ranking family of recent immigrants and hence not at all a 'barbarian' becomes irrelevant.

\section{CONCLUSIONS}

Modern scholarship uses the word 'Greek' very often in connection with the agones; far more in fact than the people visiting the games would have done in Antiquity. A good example is the tendency to characterize all 
major contests as 'Panhellenic', which does not reflect ancient usage. ${ }^{135}$ When we, almost spontaneously, describe the most popular games and sanctuaries in this way, we invite ourselves as well as our readers to see the ancient experience of these games through a Greek filter. When talking about 'Panhellenic' festivals and sanctuaries as if this was what they were called in Antiquity, we present, in other words, the Olympics as games of an imagined entity of 'Greeks', to which we attribute agency, interests and will. But as many excellent recent studies on ethnicity have shown, this stable group of 'Greeks' did never exist.

One reason why the term 'Panhellenic' seems nevertheless justified is that these agones were a custom of all the Greeks and of the Greeks alone. It has not been the aim of this paper to deny this: the way athletics was practiced in the context of the agones was indeed culturally specific, so these games did not attract participants who did not feel at home in this culture. This paper has argued, however, against the widely accepted view that non-Greeks were formally excluded from these games. This view goes back to the early research on athletics by Krause in the nineteenth-century, when it still seemed logical to think in terms of 'Greek nationality'. The idea of the exclusion of non-Greeks at Olympia survived, but created an - often avoided - problem of definition: what did it mean to be Greek and how was this checked by the authorities at the games?

I have argued that the survival of the 'only Greeks'-thesis of Krause into the post-nationalist age can be explained by a reading of Herodotus' story on the Greekness of Alexander I that takes too little account of the historian's agenda. The Greek identity of the Macedonian royals was disputed in Herodotus' lifetime, and the anecdote reflects the arguments of its advocates. When Herodotus depicts the hellanodikai as making a judgment about Alexander's ethnicity, he implies that they had the authority to do so. He stops short, however, of claiming that the exclusion of nonGreeks was an Olympic principle: this idea is presented as the personal opinion of Alexander's opponents, leading to a dispute ended by the judges. Because these judges were called hellanodikai, it has been surmised that checking ethnic eligibility was one of their standard tasks.

135 Cf. Parker 2004: 11 for the lack of a Greek equivalent to the modern term 'Panhellenic'; Scott 2010: 260-64 for the Roman origin of the term. 
However, around $500 \mathrm{BC}$, the time of Alexander's participation, the judges did not even carry this title, which was developed in the aftermath of the 480-479 wars. Read against the background of Herodotus' contemporary agenda, the Alexander anecdote contains good evidence for the association between the Olympics and ideals of panhellenism in the mid-fifth century, but proves neither that there was a system for the systematical exclusion of non-Greeks from Olympia at the time of Alexander, nor that such a system was permanently put in place around 476.

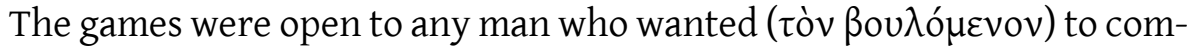
pete.

The few criteria attested for exclusion from the games are clear, legal grounds. This article analyzed the plentiful evidence for admission and registration procedures at major agones. These sources attest to the existence of: 1) an admission system for under-age athletes who wanted to compete in the youth categories, named the enkrisis; 2) a rule against the admission of slaves that was upheld by means of a reactive procedure, which allowed anyone to raise doubt about the status of a competitor; and 3) the formal registration of the official name and polis citizenship of all participants under the Roman Empire, which could lead to the refusal of athletes without citizenship. Sources for the classical and Hellenistic periods indicate that, prior to the Roman age, polis citizenship was not registered or scrutinized. The eventual introduction of a registration system did not aim to limit admission on ideological grounds, but can be better explained as part of a process of bureaucratization of agonistic procedure, driven by a need for a closer control over the privileges for victors.

The thesis that the ethnic tensions in Herodotus' anecdote about Alexander resulted in a general principle against the admission of nonGreeks is hence not confirmed by other ancient sources. It was, however, not the last time that ethnic tensions surfaced in connection to the Olympics, as another famous anecdote about the Hellenistic champion Kleitomachos, discussed in the last section, shows. The current approach to ethnicity, which focuses on situations under which an awareness of ethnic identities temporarily crystallizes, makes it possible, however, to understand such moments of ethnic tensions at the games without the premise of an exclusive admission policy. 
With Kleitomachos' plea not to support an athlete from Egypt, this paper has ended with a case in which ethnicity came into play at the Olympics - or at least in their literary representation - in a negative light, namely in a conflict of identities arising in the context of Hellenization. In the Hellenistic period festivals were, however, primarily a means of improving relations between traditional poleis and cities new to the Greek cultural sphere. When reaching out to each other, the cities in Asia Minor and Greece used a discourse of kinship. ${ }^{136}$ Cities tried to show that they were related to other cities, and that they all belonged to the same community. Some diplomatic networks were agonistic: poleis organizing new agones sent out theoroi to numerous cities to invite them to join in the festival. The catchment area of the major agones in this way adapted in a matter of decades to the spread of Greek culture. From cities in Asia, Syria and Egypt athletes travelled to the famous sanctuaries in Greece to compete.

There began to appear participants and even winners from families who had only recently started to adapt to Greek culture. In the last decades of the third century, the Philhellenic regent (sofet) of Sidon, Diotimos - probably a descendant of Abdalonymos, who was appointed regent under Alexander - won the chariot races at Nemea. ${ }^{137}$ Also from Sidon, a boxer with the typically Phoenician name Sillis won the young men's boxing on Delos in 269 BC. ${ }^{138}$ In the mid-second century, the Numidian prince Mastanabal won the Panathenaia with the two-chariot for foals. ${ }^{139}$ For Olympia Hellenistic examples are harder to find, but one could cite the Romans Gnaeus Marcus, who obtained a double victory at some point before AD 21, the equestrian successes of Tiberius Claudius Nero, the future emperor, and of his adoptive son Germanicus, or the

136 For some clearly explained cases see Stavrianopoulou 2013; more generally also Ma 2003.

137 IAG 41 = Steinepigramme 20/14/01. See Bikerman 1939 and Habicht 2007: 125-27.

138 IG XI.2 203, 1. 68. Cf. Grainger 1991: 80, 110.

139 IG II ${ }^{2}$ 2316, col. II, 42-44. Mastanabal is called "son of king Masanassos" without further identification by means of a place, as is the following victor in the list, "king Ptolemy (VI), son of the older king Ptolemy." 
boxing Armenian prince Varazdates victorious in the later fourth century AD. ${ }^{140}$ One should not forget, moreover, that the Olympic victor list is only representative for those competitors who had the ability to defeat the cream of the athletes, who had been training their physique and their discipline's techniques under the supervision of specialists for years. Because we know only a few unsuccessful athletes, we do not have a full picture of those who wanted to compete and were allowed to.

Many of the above-mentioned athletes had only a tenuous claim to Hellenic identity in comparison to the Greek credentials of Aristonikos, but the organizers of the games do not seem to have been bothered by this. Agones were not by definition exclusive events; they served as motors for the integration of new areas in the cultural area commonly described as Greek. Athletes did not compete at Olympia or at another major contest because they were accepted as Greeks; they could be perceived as Greeks because they competed here. Like the games, the road to acculturation was open for those who wanted.

140 Moretti 1957: nrs. 738, 743, 745, 750 for the Romans. Remijsen 2015: 47 for Varazdates. 


\section{BIBLIOGRAPHY}

Asirvatham, S.R. 2010. 'Perspectives on the Macedonians from Greece, Rome, and Beyond' in J. Roisman \& I. Worthington (eds.) A Companion to Ancient Macedonia. Malden, 99-124.

Badian, E. 1982. 'Greeks and Macedonians' in B. Barr-Sharrar \& E.N. Borza (eds.) Macedonia and Greece in Late Classical and Early Hellenistic Times. Washington, 33-51.

Badian, E. 1994. 'Herodotus on Alexander I of Macedon: A Study in Some Subtle Silences' in S. Hornblower (ed.) Greek Historiography. Oxford, 107-30.

Baron, C. 2013. 'Hellenotamiai' in R.S. Bagnall (eds.) The Encyclopedia of Ancient History. Chichester, 3125-26.

Beck, H. 2002. 'Thessaloi, Thessalia' in DNP 12/1, Col. 446-51.

Bernardini, P. \& M. di Marzio 2012. 'Alessandro, figlio di Aminta, e una vittoria mancata: Pindaro, frr. 120-121 Maehl.' QUCC 101, 29-41.

Bikerman, E. 1939. 'Sur une inscription grecque de Sidon' in Mélanges syriens offerts à Monsieur René Dussaud. Paris, 91-99.

Borza, E.N. 1982. 'Athenians, Macedonians, and the Origins of the Macedonian Royal House' in E. Vanderpool (ed.) Studies in Attic Epigraphy, History and Topography. Presented to Eugene Vanderpool (Hesperia Supplements 19). Princeton, 7-13.

Bresson, A. 2002. 'Un 'Athénien' à Sparte ou Plutarque lecteur de Xénophon' REG 115, 22-57.

Brubaker, R. 2004. Ethnicity without Groups. Cambridge, MA \& London.

Burstein, S. 2008. 'Greek Identity in the Hellenistic Period' in K. Zacharia (ed.) Hellenisms. Culture, Identity, and Ethnicity from Antiquity to Modernity. Farnham \& Burlington, 59-77.

Chankowski, A.S. 2010. L'éphébie hellénistique. Étude d'une institution civique dans les cités grecques des îles de la Mer Égée et de l'Asie Mineure. Paris.

Christesen, P. \& Z. Martirosova-Torlone 2006. 'The Olympic Victor List of Eusebius: Background, Text, and Translation' Traditio 61, 31-93.

Clarysse, W. \& G. van der Veken 1983. The Eponymous Priests of Ptolemaic Egypt. Chronological Lists of the Priests of Alexandria and Ptolemais with a Study of the Demotic Transcriptions of their Names. Leiden. 
Clarysse, W. \& K. Vandorpe 1995. Zénon, un homme d'affaires grec à l'ombre des pyramides. Leuven.

Crowther, N.B. 1992. 'Slaves and Greek Athletics' QUCC 40, 35-42.

Crowther, N.B. 2007. 'The Ancient Olympics and Their Ideals' in G.P. Schaus \& S.R. Wenn (eds.) Onward to the Olympics: Historical Perspectives on the Olympic Games. Ontario, 69-80.

Crowther, N.B. 1996. 'Athlete and State: Qualifying for the Olympic Games in Ancient Greece' Journal of Sport History 23, 34-43. [Reprinted in N.B. Crowther Athletika. Studies on the Olympic Games and Greek Athletics. Hildesheim 2004, 23-33 and in T. Scanlon (ed.) Sport in the Greek and Roman Worlds. Vol. 1: Early Greece, the Olympics, and Contests (Oxford Readings in Classical Studies). Oxford 2014, 143-57.]

Dascalakis, A. 1965. The Hellenism of the Ancient Macedonians. Thessaloniki. Decker, W. 1996. 'Akoniti' in DNP 1, Col. 405.

Delia, D. 1991. Alexandrian Citizenship During the Roman Principate (American Classical Studies 23). Atlanta.

Eckstein, A.M. 1995. Moral Vision in the Histories of Polybius. Berkeley.

Elsner, J. 2001. 'Structuring 'Greece': Pausanias's Periegesis as a Literary Construct' in S.E. Alcock, J.F. Cherry \& J. Elsner (eds.) Pausanias: Travel and Memory in Roman Greece. Oxford, 3-20.

Engels, J. 2010. 'Macedonians and Greeks' in J. Roisman \& I. Worthington (eds.) A Companion to Ancient Macedonia. Chichester, 81-89.

Farrington, A. 1997. 'Olympic Victors and the Popularity of the Olympic Games in the Imperial Period' Tyche 12, 15-46.

Farrington, A. 2012. Isthmionikai: A Catalogue of Isthmian Victors. Hildesheim.

Fauconnier, B. 2016. 'Athletes and Artists in an Expanding World: The Development of Ecumenical Associations of Competitors in the First Century BC' in C. Mann, S. Remijsen \& S. Scharff (eds.) Athletics in the Hellenistic World. Stuttgart, 73-93.

Freitag, K. 2013. 'Die panhellenischen Heiligtümer und die griechischen Bundesstaaten in hellenistischer Zeit' in N. Birgalias, P. Cartledge, A. Gartziou-Tatti \& M. Dimopoulou (eds.) War, Peace and Panhellenic Games. Athens, 131-48.

Frisch, P. 1988. 'Die Klassifikation der $\pi \alpha \tilde{i} \delta \varepsilon \varsigma$ bei den griechischen Agonen' ZPE 75, 179-85. 
Funke, P. 1997. 'Boiotia, Boiotoi' in DNP 2, 733-37.

Funke, P. 2006. 'Fremde und Nicht-Bürger in den griechischen Heiligtümern der antiken Mittelmeerwelt. Eine historische Einführung' in A. Naso (ed.) Stranieri e non cittadini nei santuari greci. Atti del Convegno Internazionale. Firenze, 1-12.

Galazzi, C. \& B. Kramer 2014. 'Alexandrinische Ephebenurkunden aus dem Konvolut des Artemidorpapyrus (P.Alex.Epheb.)' APF 60, 117-53. Gardiner, E.N. 1910. Greek Athletic Sports and Festivals. London.

Golden, M. 1998. Sport and Society in Ancient Greece. Cambridge.

Golden, M. 2008. Greek Sport and Social Status. Austin.

Grainger, J.D. 1991. Hellenistic Phoenicia. Oxford.

Habicht, C. 2007. 'Neues zur hellenistischen Geschichte von Kos' Chiron $37,123-52$.

Hall, J.M. 2002. Hellenicity. Between Ethnicity and Culture. Chicago \& London. Hatzopoulos, M.B. 1996. Macedonian Institutions under the Kings. 2 vols. Athens.

Heberdey, R. \& A. Wilhelm 1896. Reisen in Kilikien. Wien.

Hornblower, S. 2000. 'Thucydides, Xenophon, and Lichas: Were the Spartans Excluded from the Olympic Games from 420 to 400 B.C.?' Phoenix $54,212-25$.

Hornblower, S. 2013. Herodotus. Histories. Book V. Cambridge. Jones, C.P. 1999. Kinship Diplomacy in the Ancient World. Cambridge, MA. Jordan, D.R. 1994. 'Inscribed Lead Tablets from the Games in the Sanctuary of Poseidon' Hesperia 63, 111-26.

Jordan, D.R. \& A.J.S. Spawforth 1982. 'A New Document from the Isthmian Games' Hesperia 51, 65-68.

Jüthner, J. (ed.) 1909. Philostratos über Gymnastik. Leipzig \& Berlin.

Kennell, N.M. 2006. Ephebeia. A Register of Greek Cities with Citizen Training Systems in the Hellenistic and Roman Periods (Nikephoros. Beihefte 12). Hildesheim.

Kertész, I. 2005. 'When did Alexander I Visit Olympia?' Nikephoros 18, 11526.

Klee, T. 1918. Zur Geschichte der gymnischen Agone an den griechischen Festen. Leipzig \& Berlin. 
Koch, A. 2008. Johannes Chrysostomus und seine Kenntnisse der antiken Agonistik im Spiegel der in seinen Schriften verwendeten Bilder und Vergleiche (Nikephoros Beihefte 14). Hildesheim.

Koenen, L. 1977. Eine agonistische Inschrift aus Ägypten und frühptolemäische Königsfeste. Meisenheim am Glan.

König, J. 2005. Athletics and Literature in the Roman Empire. Cambridge.

Konstan, D. 2001. 'To Hellenikon ethnos: Ethnicity and the Construction of Ancient Greek Identity' in I. Malkin (ed.) Ancient Perspectives of Greek Ethnicity. Cambridge, MA \& London, 29-50.

Krause, J.H. 1838. Olympia, oder Darstellung der grossen olympischen Spiele und der damit verbundenen Festlichkeiten. Wien [reprinted Hildesheim \& New York 1972].

Kyle, D.G. 2010. 'Pan-Hellenism and Particularism: Herodotus on Sport, Greekness, Piety and War' in Z. Papakonstantinou (ed.) Sport in the Cultures of the Ancient World. New Perspectives. London \& New York, 35-63.

Kyle, D.G. 2014. 'Greek Athletic Competitions. The Ancient Olympics and More' in P. Christesen \& D.G. Kyle (eds.) A Companion to Sport and Spectacle in Greek and Roman Antiquity. Chichester, 21-35.

Legras, B. 1999. Néotês. Recherches sur les jeunes grecs dans l'Égypte ptolémaïque et romaine. Genève.

Luraghi, N. 2014. 'The Study of Greek Ethnic Identities' in J. McInerney (ed.) A Companion to Ethnicity in the Ancient Mediterranean. Oxford, 21327.

Ma, J. 2003. 'Peer Polity Interaction in the Hellenistic Age' Past and Present $180,7-38$.

Malkin, I. 2001. 'Introduction' in I. Malkin (ed.) Ancient Perceptions of Greek Ethnicity. Cambridge, MA, 1-28.

Mann, C. 2001. Athlet und Polis im archaischen und frühklassischen Griechenland (Hypomnemata 138). Göttingen.

Moretti, L. 1957. 'Olympionikai, i vincitori negli antichi agoni olimpici' RAL 8, 53-198.

Morgan, C. 1993. ‘The Origins of Pan-Hellenism' in N. Marinatos \& R. Hägg (eds.) Greek Sanctuaries. New Approaches. London \& New York, 18-44.

Morgan, K.A. 2015. Pindar and the Construction of Syracusan Monarchy in the Fifth Century B.C. Oxford. 
Nielsen, T.H. 2007. Olympia and the Classical Hellenic City-State Culture (Historisk-filosofiske Meddelelser 96). Copenhagen.

Nielsen, T.H. 2014. 'Panhellenic Athletics at Olympia' in P. Christesen \& D.G. Kyle (eds.) A Companion to Sport and Spectacle in Greek and Roman Antiquity. Chichester, 133-45.

Papakonstantinou, Z. 2016. 'The Hellenistic Agonothesia: Finances, Ideology, Identities' in C. Mann, S. Remijsen \& S. Scharff (eds.) Athletics in the Hellenistic World. Stuttgart, 95-112.

Parker, R. 2004. 'New Panhellenic Festivals in Hellenistic Greece' in R. Schlesier \& U. Zellmann (eds.) Mobility and Travel in the Mediterranean from Antiquity to the Middle Ages. Münster, 9-22.

Remijsen, S. 2011. 'The So-called 'Crown-games': Terminology and Historical Context of the Ancient Categories for Agones' ZPE 177, 97-109.

Remijsen, S. 2014. 'Greek Sport in Egypt: Status Symbol and Lifestyle' in P. Christesen \& D.G. Kyle (eds.) A Companion to Sport and Spectacle in Greek and Roman Antiquity. Chichester, 349-63.

Remijsen, S. 2015. The End of Greek Athletics in Late Antiquity. Cambridge. Rigsby, K.J. 1996. Asylia. Territorial Inviolability in the Hellenistic World. Berkeley.

Romeo, I. 2002. 'The Panhellenion and Ethnic Identity in Hadrianic Greece' CPh 97, 21-40.

Roos, P. 1985. 'Alexander I in Olympia' Eranos 83, 162-68.

Rutherford, I. 2013. State Pilgrims and Sacred Observers in Ancient Greece: A Study of Theōriā and Theorōi. Cambridge \& New York.

Scanlon, T.F. 2002. Eros and Greek Athletics. Oxford.

Scharff, S. 2016. 'Das Pferd Aithon, die Skopaden und die $\pi \alpha \tau \rho i ́ c$ $\Theta \varepsilon \sigma \sigma \alpha \lambda i ́ \alpha$. Zur Selbstdarstellung hippischer Sieger aus Thessalien im Hellenismus' in C. Mann, S. Remijsen \& S. Scharff (eds.) Athletics in the Hellenistic World. Stuttgart, 209-29.

Scott, M. 2010. Delphi and Olympia. The Spatial Politics of Panhellenism in the Archaic and Classical Periods. Cambridge.

Siapkas, J. 2014. 'Ancient Ethnicity and Modern Identity' in J. McInerney (ed.) A Companion to Ethnicity in the Ancient Mediterranean. Oxford, 6681.

Peter, S. \& J. Taita 2014. 'Funktionäre Olympias auf einem hocharchaischen Bronzeblech (BrU 6)' Tyche 29, 183-91. 
Sinn, U. 2004. Das antike Olympia. Götter, Spiel und Kunst. München.

Slater, W. 2015. 'Victory and Bureaucracy: The Process of Agonistic Rewards' Phoenix 69, 147-69.

Spivey, N. 2004. The Ancient Olympics. Oxford.

Sprawski, S. 2010. 'The Early Temenid Kings to Alexander I' in J. Roisman

\& I. Worthington (eds.) A Companion to Ancient Macedonia. Malden, 12744.

Stavrianopoulou, E. 2013. 'Hellenistic World(s) and the Elusive Concept of Greekness' in E. Stavrianopoulou (ed.) Shifting Social Imaginaries in the Hellenistic Period: Narrations, Practices, and Images. Leiden, 177-205.

Weiler, I. 2008. 'Fragen zur Qualifikation und Zulassung von Teilnehmern bei den Olympischen Spielen in der Antike' in C. Wacker \& R. Marxen (eds.) Olympia - Ideal und Wirklichkeit: Festschrift für Norbert Müller zum 60. Geburtstag. Berlin \& Münster, 179-205.

West, W.C. 1966. Greek Public Monuments of the Persian Wars, Diss. University of North Carolina [available online: http://chs.harvard.edu/ CHS/article/display/5569].

Wilson, N.G. 2015. Herodotea: Studies on the Text of Herodotus. Oxford.

Wolicki, A. 2002. 'The Heralds and the Games in Archaic and Classical Greece' Nikephoros 15, 69-97.

Zahrnt, M. 2010. 'Marathon - das Schlachtfeld als 'Erinnerungsort', einst und jetzt' in E. Stein-Hölkeskamp \& K.-J. Hölkeskamp (eds.) Die griechische Welt. Erinnerungsorte der Antike. München, 114-27.

Zoumbaki, S. 2011. 'Hellanodiken außerhalb von Olympia' Tekmeria 10, 721.

Sofie Remijsen

University of Amsterdam

S.M.J.Remijsen@uva.nl 